\title{
Type 2 Diabetes Mellitus and Glucagon Like Peptide-1 Receptor Signalling
}

\section{Aiysha Thompson and Venkateswarlu Kanamarlapudi*}

Institute of Life Science 1, College of Medicine, Swansea University, Singleton Park, Swansea, SA2 8PP, UK

\begin{abstract}
It has been estimated that approximately $8.4 \%$ of the world population currently live with diabetes mellitus and type 2 diabetes is the most common form. Type 2 diabetes increases the risk of complications such as heart attacks, blindness, amputations and kidney failure. Glucagon like Peptide-1 (GLP-1) is an effective insulinotropic agent and therefore its effects on insulin secretion have been greatly examined for more than two decades. It is a polypeptide hormone secreted by the intestinal L-cells into the blood in response to food uptake. GLP-1 has a very short half-life in vivo due to the rapid proteolytic degradation by Dipeptidyl Peptidase IV (DPP-IV). Therefore DPP-IV resistant GLP-1 analogues, Exenatide and Liraglutide, have been developed and are currently being used in the treatment of type 2 diabetes. GLP-1 agonist functions by binding to its receptor, GLP1R, on the cell surface.

The GLP-1R belongs to the class B peptide receptor family based on its structure and function. The binding of GLP-1 to its receptor results in activation of Gas coupled adenylyl cyclase and the production of cyclic Adenosine Monophosphate (cAMP), which enhances glucose-induced insulin secretion. Continuous GLP-1R activation also causes insulin secretion and pancreatic islet $\beta$-cell proliferation and neogenesis. The GLP-1R is internalised following its activation, which regulates the biological responsiveness of the receptor. Structurally the GLP-1R contains a large N-terminal extracellular domain (TM1-TM7) joined by three intracellular loops (ICL1, ICL2, ICL3) and three extracellular loops (ECL1, ECL2, ECL3), and an intracellular C-terminal domain. These domains play critical roles in GLP-1R trafficking to the cell surface, and also in agonist dependent activation and internalisation of the receptor. This review is focused on type 2 diabetes, its treatment with GLP-1, GLP-1R structure and function, and the physiological affects resulting from GLP-1R activation.
\end{abstract}

Keywords: Diabetes mellitus; GLP-1; GLP-1R; GPCR; Insulin; Signalling

\section{Introduction}

The actions of Glucagon like peptide-1 (GLP-1) have been greatly examined over the last twenty years, due to the hormones effectiveness at lowering blood glucose levels and increasing insulin secretion in type 2 diabetic patients [1,2]. GLP-1 exerts its actions through the GLP-1 Receptor (GLP-1R), a family B G-Protein Coupled Receptor (GPCR) which mediates its effects through the Gas subunit, which in turn activates Adenylyl Cyclase (AC). The involvement of Gas and subsequent accumulation of cyclic Adenosine Monophosphate (cAMP) in glucose-induced insulin secretion is well established [3].

\section{Type 2 Diabetes}

\section{Background}

The World Health Organization describes diabetes mellitus as a "metabolic disorder of multiple actiology characterised by chronic hyperglycemia with disturbances of carbohydrate, fat and protein metabolism resulting from defects in insulin secretion, insulin action, or both" [4,5]. It was estimated that 366 million people $(8.4 \%$ of the world's adult population) lived with diabetes in 2011 [6]. This number will continue to rise and has been estimated to reach 439 million by 2030 [7]. Diabetes remains the leading cause of blindness, end stage renal disease, lower limb amputation, and cardiovascular disease $[8,9]$. Diabetes mellitus is classified into four categories, type 1, type 2, other specific types and gestational diabetes (Table 1 ) of which type 2 is the most common form $[4,5,10]$.

\section{Pathophysiology and causes}

Insulin is a hormone that is secreted in response to food uptake to maintain glucose homeostasis. It is produced by the $\beta$-cells in the islet of Langerhans in the pancreas [11]. Synthesis occurs on the rough Endoplasmic Reticulum (ER) as preproinsulin, containing a signal peptide that is cleaved to form proinsulin (Figure 1). Proinsulin then

\begin{tabular}{|c|c|}
\hline Types & Description and Subtypes \\
\hline Type 1 & $\begin{array}{l}\beta \text {-cell destruction, usually leading to absolute insulin deficiency } \\
\text { Autoimmune } \\
\text { Idiopathic }\end{array}$ \\
\hline Type 2 & $\begin{array}{l}\text { Ranging from predominantly insulin resistant with relative } \\
\text { insulin deficiency to a predominantly secretory defect with or } \\
\text { without insulin resistance }\end{array}$ \\
\hline $\begin{array}{l}\text { Other } \\
\text { Specific } \\
\text { Types }\end{array}$ & $\begin{array}{l}\text { Genetic defects of } \beta \text {-cell function } \\
\text { Genetic defects in insulin action } \\
\text { Diseases of the exocrine pancreas } \\
\text { Endocrinopathies } \\
\text { Drug- or chemical induced } \\
\text { Infections } \\
\text { Uncommon form of immune-mediated diabetes } \\
\text { Other genetic syndromes sometimes associated with } \\
\text { diabetes }\end{array}$ \\
\hline $\begin{array}{l}\text { Gestational } \\
\text { Diabetes }\end{array}$ & $\begin{array}{l}\text { Carbohydrate intolerance resulting in hyperglycaemia of } \\
\text { variable severity with onset or first recognition during } \\
\text { pregnancy }\end{array}$ \\
\hline
\end{tabular}

Diabetes mellitus is classified into four categories, type 1, type 2, other specific types and gestational diabetes

Table 1: Aetiological classification of disorders of glycaemia.

*Corresponding author: Venkateswarlu Kanamarlapudi, Institute of Life Science 1, College of Medicine, Swansea University, Singleton Park, Swansea, SA2 8PP, UK, Tel: +44 1792 295012; Fax: +44 1792 602147; E-mail: k.venkateswarlu@swansea.ac.uk

Received October 08, 2013; Accepted October 25, 2013; Published November 01, 2013

Citation: Thompson A, Kanamarlapudi V (2013) Type 2 Diabetes Mellitus and Glucagon Like Peptide-1 Receptor Signalling. Clin Exp Pharmacol 3: 138. doi:10.4172/2161-1459.1000138

Copyright: (c) 2013 Thompson A, et al. This is an open-access article distributed under the terms of the Creative Commons Attribution License, which permits unrestricted use, distribution, and reproduction in any medium, provided the original author and source are credited. 


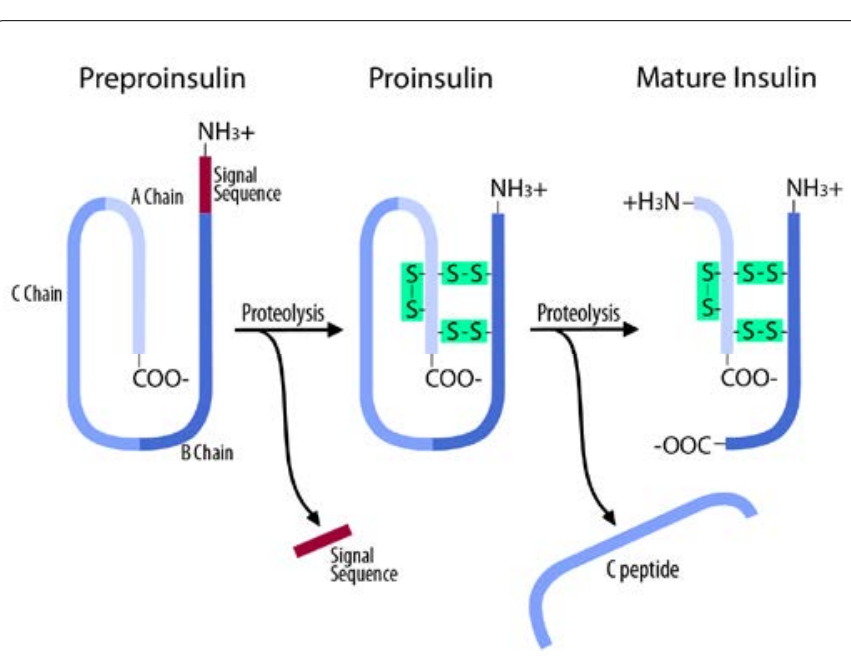

Figure 1:Processing of Preproinsulin. The signal peptide sequence (23 amino acids) is removed from the $\mathrm{N}$-terminus of preproinsulin by proteases. This forms three disulphide bonds producing proinsulin. Further proteolytic cleavage of proinsulin removes the C-peptide producing mature insulin. Redrawn from [12].

traffics through the trans golgi network and packaged into secretory vesicles until required [12]. The hydrolysis of dietary carbohydrates such as starch or sucrose within the small intestines results in the production of glucose that is then absorbed into the blood. An increase in glucose concentrations in the blood stimulates the release of insulin. Insulin has different effects depending on the target tissue; it either facilitates the entry of glucose into adipose and muscle tissue or stimulates the liver to store glucose as glycogen. If insulin is absent or in low concentrations within the body, insulin sensitive cells are unable to absorb glucose and therefore use other fuel sources such as fatty acids for energy. When blood glucose levels are low, insulin is not produced and instead glucagon is secreted, broken down and released as glucose $[13,14]$.

In normal individuals, glucose homeostasis keeps glucose levels under control and within the normal range of 80 to $120 \mathrm{mg} / 100 \mathrm{ml}$ (4.4-6.7 mM). For patients with diabetes, insufficient insulin release results in hyperglycemia and high blood glucose levels [14,15]. An absolute lack of insulin producing $\beta$-cells in the pancreas results in the development of type 1 diabetes $[4,5,16]$. In contrast, type 2 diabetes is a result of insulin dependent cells not being able to respond to insulin effectively, also known as insulin resistance [4,5]. It is being noticed that type 2 diabetes only develops in patients who are insulin resistant with the onset of $\beta$-cell dysfunction [17].

It is estimated that $60-90 \%$ of patients with type 2 diabetes are obese, and obesity itself can cause or aggravate insulin resistance [18]. There is a greater than 90 -fold increase in developing type 2 diabetes if you are obese [19]. Body Mass Index (BMI) is defined as the individual's body weight divided by the square of their height $\left(\mathrm{kg} / \mathrm{m}^{2}\right)$, and a BMI greater than 25 is overweight and above 30 is obese [20]. It is suggested that patients with type 2 diabetes aim for a BMI of 25 or below [21]. However, there is still a 2.4 -fold increased risk of developing type 2 diabetes in those who are of normal BMI (between 18.5 and 24.9) but have an increased percentage of body fat distributed in the abdominal region [22-24].

Diet, sedentary lifestyle and genetics all play a role in the development of type 2 diabetes $[7,25,26]$. The dietary intake of saturated fat, trans-fatty acids and total fats was considered risk factors in the development of type 2 diabetes. In contrast dietary fibres or non-starch polysaccharides were considered protective factors [25]. Low-fat vegetarian and vegan diets have the potential to be used for the management of type 2 diabetes because they are associated with weight loss; improve cardiovascular health and increase insulin sensitivity $[27,28]$. A cohort study evaluated the association of multiple lifestyle factors, including diet, physical activity, alcohol use, smoking habits and adiposity measures, with the risk of developing type 2 diabetes. It was found to be approximately $50 \%$ lower in individuals whose physical activity and dietary habits indicated low risk and approximately $80 \%$ lower in those whose physical activity, dietary habits, alcohol use and smoking habits all indicated low risk [24,29]. In addition, having relatives with type 2 diabetes substantially increases the chance of developing type 2 diabetes. The Insulin Receptor Substrate-1 (IRS-1) gene has been associated with type 2 diabetes, insulin resistance and hyperinsulinemia in a large scale study that screened 14,000 people all around the world [30].

\section{Signs and symptoms}

Type 2 diabetes often develops slowly from a condition of prediabetes, and symptoms may not be apparent for years [7]. The characteristic symptoms of type 2 diabetes including; dehydration, blurred vision, excessive thirst, polydipsia (increased fluid intake) and polyuria (excessive urine production); can develop because of hyperglycaemia. In diabetes, insulin producing $\beta$-cells are either partially or completely unable to use glucose as a fuel and therefore switch to using fat, carbohydrates and protein metabolism as a fuel source instead. This process requires more energy and leads to polyphagia (excessive eating), weight loss and lethargy [4,5,31]. Additionally, hyperglycaemia can lead to skin infection as a result of open and slow healing sores because it is more difficult for the body to heal itself [32].

Serious long-term complications of type 2 diabetes include nerve dysfunction, cardiovascular disease, microvascular damage, renal failure, blindness, impotence and poor wound healing and are a result of prolonged hyperglycaemia $[4,5,33]$. These complications may also occur if the disease is controlled inappropriately. Hypoglycemia is caused by inaccurately administered insulin. A shortage of insulin causes the body to switch to metabolising fatty acids and as a result produces ketone bodies. This response results in ketoacidosis and causes dehydration in addition to many of the symptoms and complications already described [34]. Another metabolic complication is known as hyperglycaemia hyperosmolar state and is the end result of sustained osmotic diuresis. It is characterised by severe hyperglycaemia, hyperosmolarity, and dehydration, but without the significant ketoacidosis hyperosmolar hyperglycemic state $[34,35]$.

\section{Diagnosis}

Diabetes is diagnosed by recurrent or persistent hyperglycaemia. This can be demonstrated by any of the following criteria: a fasting plasma glucose level of $7.0 \mathrm{mM}$; a single plasma glucose reading in excess of $11.1 \mathrm{mM}$; and an Oral Glucose Tolerance Test (OGTT) administered two hours after $75 \mathrm{~g}$ oral glucose with fasting plasma glucose concentrations in excess of $11.1 \mathrm{mM}[4,5]$.

Glycosylation of haemoglobin (HbAlc) is primarily used as a treatment-tracking test and reflects average glucose levels over 8-12 weeks [36,37]. Measurements can be performed at any time and there is no need for fasting. It is recommended that HbAlc be used to measure blood glucose control in both pre-diabetics and patients with diabetes. A reading of $6.5 \% \mathrm{HbA} 1 \mathrm{c}$ or above is used to diagnose diabetes [37]. OGTT or intravenous glucose tolerance tests are used 
to determine insulin response of the pancreas and degree of insulin resistance. However, it was noted that glucose administered orally promoted a significantly greater insulin response than glucose administered intravenously (Figure 2), although plasma glucose levels were the same [38-40]. Further, cross reactivity with partially degraded proinsulin and insulin may occur and as a result insulin measurement may be problematic. It is especially problematic in patients who have developed anti-insulin antibodies through administering animal insulin. As a result, C-peptide concentration has been used as a semi quantitative measure of $\beta$-cell secretory activity instead of insulin itself. C-peptide has a half-life 2.5 times longer than insulin and therefore higher concentrations exist in the peripheral circulation and levels fluctuate less [41].

\section{Approaches and goals for the treatment of type $\mathbf{2}$ diabetes}

More intensive glucose control, mainly determined by HbAlc levels, can delay or prevent the development and progression of serious complications in type 2 diabetics [33]. Initial treatment of type 2 diabetes generally begins with non-pharmacological interventions such as diet, lifestyle and exercise. These interventions combined with antihyperglycaemic agents (such as metformin) are expected to improve blood glucose control. If an HbAlc level greater than $7 \%$ is not achieved within 2-3 months, then the recommended second stage is the addition of hypoglycaemic agents (such as sulfonylureas) or insulin injections to the treatment. Hypoglycaemic agents reduce plasma glucose levels by increasing insulin secretion, reducing insulin resistance and/ or delaying glucose absorption in the gut [42-44].

In many cases treatment with either antihyperglycaemic or hypoglycaemic agents is not usually enough to achieve adequate blood glucose control and therefore insulin therapy is intensified $[42,45,46]$. However, insulin therapy has a number of risks associated with it including, hypoglycaemia, weight gain, and increased risk of colorectal cancer [47]. These risk factors together with the route of administration (usually subcutaneous injection); contribute too many patients being reluctant to maintain intensive insulin therapy [48].

Consequently, these classic treatments are often unsatisfactory and there is an imperative need for new classes of glucose lowering agents. Recently, incretin-based therapies have been used in the treatment of type 2 diabetes; namely Exenatide and Liraglutide. These drugs have the ability to preserve normal physiological responses to food intake and improve glycaemic control.

\section{GLP-1 Treatment for Type 2 Diabetes}

\section{Incretin hormones}

Incretins are gastrointestinal hormones that contribute to postprandial insulin release $[40,49]$. GLP-1 and Glucose-dependent Insulinotropic Polypeptide (GIP) are two major incretins and are thought to be responsible for up to $70 \%$ of insulin secreted from the $\beta$-cells of the pancreas following food intake. This increase in insulin is called the 'incretin effect' and maintains glucose concentrations at low levels irrespective of the amount of glucose ingested. This is achieved by increasing the sensitivity of $\beta$-cells to glucose [50]. The incretin effect' has been shown to be either reduced or absent in type 2 diabetics due to the loss of insulinotropic activity of GLP-1 and GIP. However, more recently it's been suggested that the secretion of GIP and GLP-1 is normal in type 2 diabetic patients [51]. This strongly suggests a role for incretin hormones or their actions in the treatment of type 2 diabetes [39,52-55].

The GIP gene is mainly expressed in K-cells and enterochromaffin cells of the proximal small intestine. GIP secretion is stimulated by enteral glucose, lipids and products of meal digestion in a concentration dependent manner [56]. In patients with type 2 diabetes, GIP concentrations after food intake are either normal or slightly elevated. GIP infusion does not reduce plasma glucose concentrations in patients with type 2 diabetes. As a result GIP has not been thought of as a suitable candidate for therapeutic development [57,58]. In contrast, patients with type 2 diabetes have decreased GLP-1 activity $[53,55,59]$. It is currently unknown whether reduced GLP-1 activity is a cause or consequence of diabetes. First degree relatives of patients with type 2 diabetes have normal GLP-1 activity in response to glucose, this suggests that a reduction in GLP-1 activity seen in type 2 diabetic patients is more likely acquired [60,61]. Additionally, GLP-1 is able to stimulate glucose-dependent insulin secretion in type 2 diabetic patients under hyperglycaemic conditions [54,62,63]. Furthermore, administration of exogenous GLP-1 to type 2 diabetic patients leads to normalisation of hyperglycaemic conditions $[54,64,65]$. As a result, GLP-1 based strategies appear an interesting and more suitable target for the treatment of type 2 diabetes [66].

\section{Synthesis and secretion of GLP-1}

GLP-1 is 42 amino acids in length and is synthesised from the posttranslational modification of proglucagon, by Prohormone Convertase 1 (PC1) within the intestinal L-cells. PC1 is specific to GLP-1 production in the L-cells $[67,68]$. The proglucagon gene (Figure $3 \mathrm{~A}$ ) is expressed in both the pancreatic a-cells and in the intestinal L-cells, but posttranslational processing differs in these two tissues [6971]. In the pancreatic $a$-cells (Figure $3 \mathrm{~B}$ ), proglucagon is processed to glucagon, Intervening Peptide-1 (IP1), Major Proglucagon Fragment (MPGF), and Glicentin-related Pancreatic C-peptide (GRPP) by Prohormone Convertase 2 (PC2) [68,72]. In the intestinal L-cells (Figure 3C), proglucagon is cleaved to GLP-1, Glucagon like Peptide-2 (GLP-2), Intervening Peptide-2 (IP2), oxyntomodulin and glicentin by PC1 [73-75]. However, emerging evidence suggests that pancreatic a-cells can also adapt to produce GLP-1 with recombinant expression of PC1 [76-78].

In secretory vesicles, the first six amino acids of GLP-1 are cleaved from the $\mathrm{N}$-terminus forming the bioactive peptides. Approximately $80 \%$ of truncated GLP-1 forms the predominantly secreted GLP1 (7-36)-NH2 and the remaining $20 \%$ is released as GLP-1 (7-37) (Figure 3D) [79]. Both GLP-1 (7-36)-NH2 and GLP-1 (7-37) bind to the GLP-1R with similar affinity and shows similar potency [80]. GLP-1 is produced in response to food intake, in particular glucose
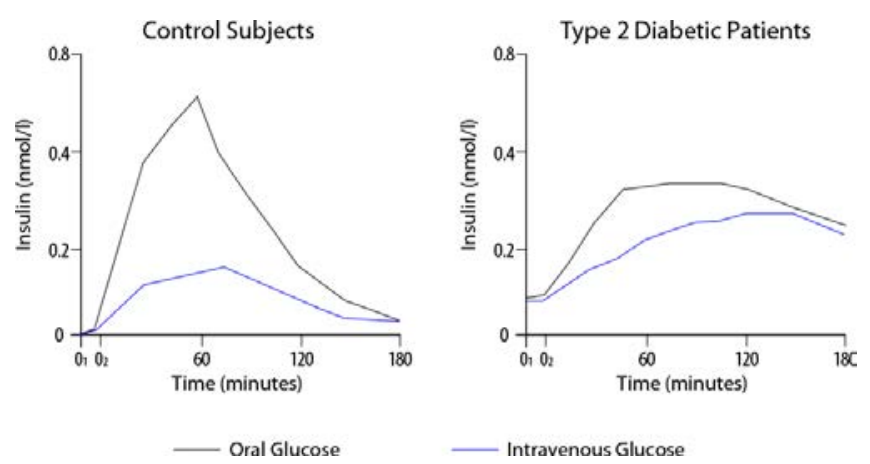

Figure 2: The Incretin Effect in Healthy Subjects and Type 2 Diabetic Patients. Venous insulin levels after oral glucose load $(50 \mathrm{~g} / 400 \mathrm{ml})$ and during intravenous glucose in healthy subjects and type 2 diabetic patients. Redrawn from [39]. 


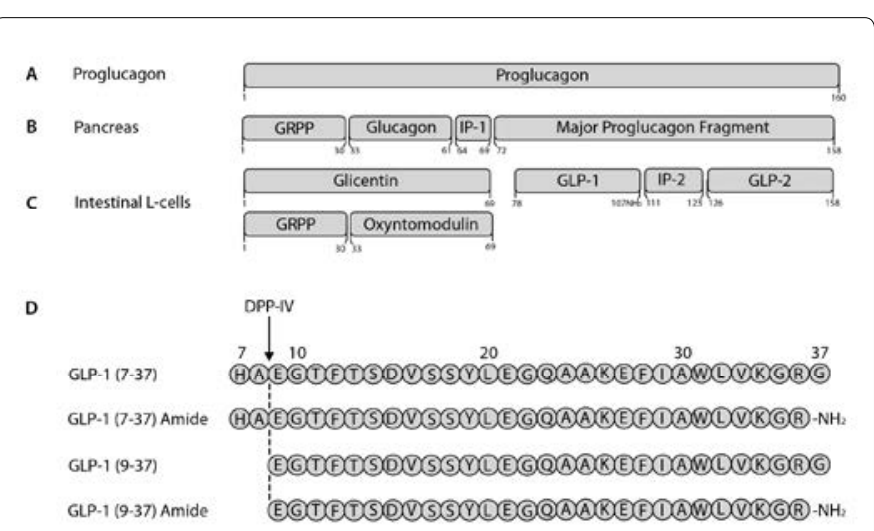

Figure 3: The Posttranslational Processing of Proglucagon and GLP-1. In the pancreas, proglucagon (A) is cleaved to glucagon, GRPP, IP1 and MPGF by PC2, which comprise amino acids $33-61,1-30$ and $72-158$ of proglucagon, respectively $(B)$. In the intestinal L-cells proglucagon is processed by PC3 to GLP-1, GLP-2, IP2, oxyntomodulin and glicentin which are composed of amino acids 78-107, 126-158, 111-123 and 33-69 of proglucagon respectively (C). GLP-1 (7-37) and GLP-1 (7-36) amide are the active forms of GLP-1 in the body, both are quickly degraded by DPP-IV into inactive GLP-1 (9-37) and GLP-1 (9-36) amide, respectively, as indicated (D). The cleavage site is indicated by the arrow.

and triacylglycerols, and lowers blood glucose levels [49,81]. In times of fasting, GLP-1 plasma concentrations are very low and can be lowered even further with administration of somatostatin in humans, suggesting there are some basal rates of secretion [69]. Typically, 'total' GLP-1 concentrations are about $5-15 \mathrm{pmol} / 1$ in basal state, rising to about 20-60 pmol/l after food intake [49]. The secretion of GLP-1 from L-cells increases in about 10 minutes after food intake, which is later than the 'cephalic phase' stimulation of insulin secretion. This suggests that neuronal signals generating insulin release does not influence GLP-1 secretion. Evidence suggests that the presence of nutrients in the gut and the interaction with the microvilli of L-cells are responsible for GLP-1 secretion [69].

In vivo, GLP-1 has a very short half-life of 1.5 minutes due to the rapid proteolytic degradation by enzyme Dipeptidyl Peptidase-IV (DPP-IV) [82-85]. This enzyme cleaves the active GLP-1 (7-36) to its inactive GLP-1 (9-36) form by removing two amino acids at the N-terminus of the peptide [86-88]. GLP-1 (9-36) and GLP-1 (9-37) (Figure 3D) have both been identified as products of GLP-1 cleavage by DPP-IV action in vitro and in vivo [84]. The degradation occurs so quickly that less than $25 \%$ of active GLP-1 that is secreted enters the portal vein prior to reaching the liver [89]. As a result, it is estimated that approximately $85 \%$ of circulating postprandial GLP-1 is either GLP-1 (9-36) or GLP-1 (9-37) [90].

\section{Biological activities of GLP-1}

GLP-1 has several actions in various tissues and exerts its effects through its cell surface receptor, the GLP-1R (Figure 4). Structurally related members of the glucagon family of peptides such as GLP-2, glucagon and GIP do not bind the GLP-1R at physiologically relevant concentrations [69]. The human GLP-1R gene is transcribed in pancreatic islet, brain, heart, intestine, kidney, liver, lung and stomach. However, the actions of GLP-1 in fat and muscle most likely occur through indirect mechanisms and do not occur in many species [9194]. The expression of the GLP-1R is consistent with the roles of GLP-1 in glucose homeostasis, $\beta$-cell proliferation, heart rate, food intake and appetite and even learning [91].

In the pancreas, GLP-1 increases insulin secretion from islet $\beta$-cells and suppresses glucagon secretion for islet $\alpha$-cells, in a glucose dependent manner $[95,96]$. Additionally, GLP-1 has been shown to promote $\beta$-cell proliferation and neogenesis, while preventing apoptosis [97-99]. In the gastro intestinal tract, GLP-1 delays gastric emptying and acts as a postprandial satiety signal to the brain to suppress appetite and food intake [56,100]. Furthermore, GLP-1 plays an important role in the enteric and central nervous system. The release of GLP-1 is tightly regulated and involves the gut-to-brain and the brain-to-periphery axis [101-103]. Pharmacological applications of GLP-1 have demonstrated a number of positive affects in the cardiovascular system, suggesting GLP-1 may play an important role in that system [104]. Additionally, evidence suggests GLP-1 and its receptor may modulate components of the insulin signalling pathway and decrease hepatic steatosis in vitro [94].

Interestingly, evidence is emerging to suggest GLP-1 (9-36) and GLP-1 (9-37), the inactive forms of GLP-1, have insulin-like actions on heart, liver and vasculature and strongly reduce activity on the GLP-1R of $\beta$-cells. It has therefore been proposed that they may act through a novel signalling pathway by binding to a different cell surface receptor [105].

\section{GLP-1 based therapies}

The binding of GLP-1 to its receptor results in insulin secretion from pancreatic $\beta$-cells, making them an important target in the treatment of type 2 diabetes. The biological and pharmacological activities of GLP-1 have been the basis for two type 2 diabetic therapies. The first therapy is based on the use of DPP-IV inhibitors to prevent the breakdown of GLP-1 from its active to inactive form [66]. The second therapy is based on the use of DPP-IV resistant GLP-1 mimetics that replicate the

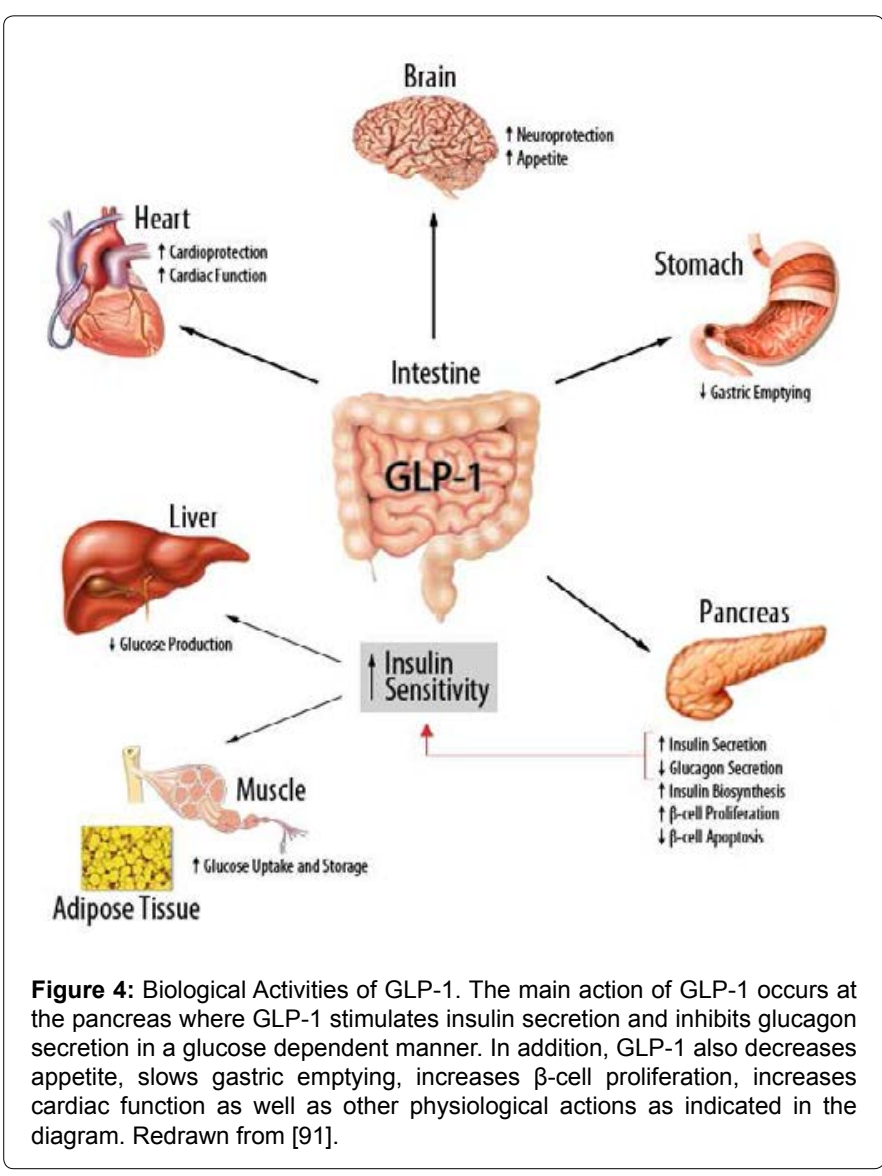


physiological actions of the native GLP-1 peptide but with a longer halflife. DPP-IV, also named adenosine deaminase complexin G-protein or CD26 (cluster of differentiation 26), is an antigenic enzyme. It is associated with signal transduction, immune regulation and apoptosis and therefore is expressed on the surface of most cell types. DPP-IV is highly specific and cleaves between $\mathrm{X}$-proline and $\mathrm{X}$-alanine dipeptides (where $\mathrm{X}$ is any amino acid) at the $\mathrm{N}$-terminus, but is unable to cleave peptides with a third proline (for example glycine-proline-proline) [84]. DPP-IV inhibitors increase GLP-1 levels by 2-3 fold over 24 hours by inhibiting $90 \%$ of plasma DPP-IV activity in vivo. They also have an additional advantage of oral administration [106]. There are currently three DPP-IV inhibitors, saxagliptin, sitagliptin and vildagliptin, used in the treatment of type 2 diabetes in Europe [107]. These inhibitors significantly decrease postprandial glucose levels and $\mathrm{HbA1c}$ by 0.5 $1.0 \%[66,108]$. Sitagliptin and vildagliptin have been shown to improve $\beta$-cell function and reduce systolic blood pressure [109]. However, the long-term inhibition of DPP-IV may have adverse effects because this enzyme is expressed in many types of tissues and has many functions [110]. Experimental evidence has demonstrated an increase in infection and some tumours, supporting adverse immunological and oncological effects after prolonged use of DPP-IV inhibitors [111].

The main limitation of GLP-1 is a very short half-life (1.5 minutes) due to the rapid proteolytic degradation of GLP-1 by DPP-IV, cleaving the active GLP-1 (7-36) to the inactive GLP-1 (9-36) form [82,83,85]. DPP-IV cleaves GLP-1 between alanine and glutamic acid at positions 8 and 9. A substitution at position 8 from alanine to valine ( $\left.\mathrm{Ala}{ }^{8} \mathrm{Val}\right)$ stabilises the peptide without affecting it activity and prevents peptide degradation. However, the half-life of the modified peptide is still too short (4-5 minutes) to be used as a drug [112]. As a result therapeutic strategies that activate the GLP-1R and improve GLP-1 actions have been extensively studied and developed. This has led to the development of two DPP-IV resistant GLP-1R agonists, Liraglutide and Exenatide. Liraglutide is a long-acting GLP-1 analogue with $97 \%$ sequence homology to human GLP-1 [113]. It is chemically similar to human GLP-1 but with structural modifications resulting in resistance to GLP-1 inactivation by DPP-IV and prolonged duration of action [114]. Liraglutide has a half-life of approximately 11-13 hours and it is administered once a day irrespective of meal times [115]. Exenatide is a peptide found within the salivary glands of the Gila monster lizard and has $52 \%$ sequence homology to GLP-1 [116]. It is also not enzymatically degraded by DPP-IV and therefore has a prolonged in vivo half-life of 3.4-4 hours compared with GLP-1. As a result it is administered twice daily within 60 minutes of a meal [117]. Both GLP-1R agonists are currently in use as drugs for the treatment of type 2 diabetes, as they are effective insulinotropic agents regulating blood glucose levels by increasing insulin secretion and supressing glucagon secretion in a glucose dependent manner [118,119]. Liraglutide and Exenatide significantly reduce both fasting and postprandial glucose levels and HbAlc levels by $0.8-1.5 \%$ [113]. The most common side effects of GLP-1 strategies are dyspepsia or nausea, which may lead to delayed gastric emptying. However, the effects seem to subside with continuous administration $[66,120]$. Acute pancreatitis has been reported in a few rare cases but their clinical significance remains unclear [121]. These side effects associated with the long-term administration of these peptides have necessitated the search for orally active small molecule agonists of the GLP-1R [122].

A series of eleven-amino acid peptide, agonists of the GLP-1R, have been reported to have excellent potency and in vivo activity in $\mathrm{ob} / \mathrm{ob}$ mouse models of diabetes [123,124]. These peptides are closely related structurally to nine C-terminal residues of GLP-1 but are substituted with several unnatural amino acids at position 11, such as homohomophenylalanine. This gives rise to the opportunity to increase stability against proteolytic degradation by DPP-IV. However, the activity of these peptides can be blocked with inactive exendin (939) (exendin antagonist) [124].

\section{The GLP-1R in Type 2 Diabetes}

\section{Characterisation of the GLP-1R}

Regulation of GLP-1R expression and function is clinically important because of its role in GLP-1 based therapy for type 2 diabetes. The GLP-1R belongs to a group of receptors known as GPCRs (also named seven transmembrane receptors). They are the largest family of cell surface receptors and are the most common target for medical therapeutics due to their involvement in many physiological and pathological processes. Over $50 \%$ of drugs available on the market act on GPCRs [125]. All GPCRs are made up of a single polypeptide chain of up to 1100 amino acid residues, which pass through the plasma membrane seven times. This membrane topology results in an extracellular $\mathrm{N}$-terminal domain, seven transmembrane $\alpha$-helices joined by three Extracellular Loops (ECL) and three Intracellular Loops (ICL) followed by an intracellular C-terminal domain that interacts with $\mathrm{G}$ proteins (Figure 5). GPCRs are classically divided into three classes: $\mathrm{A}, \mathrm{B}$ and $\mathrm{C}$ based on their sequence homology and functional similarities [126].

The GLP-1R belongs to the family B GPCRs, also known as the secretin receptor family and is made up of only 15 members $[126,127]$. This family is distinguishable from the other two families by the large $\mathrm{N}$-terminal extracellular domain that is $100-160$ amino acids in length and has an important role in agonist binding (Figure 5B). Additionally, this family contains several conserved disulphide bonds in the $\mathrm{N}$-terminus of the receptor, which stabilises the large $\mathrm{N}$-terminal structure [127]. The gene encoding the GLP-1R is located on the short arm of chromosome $6(6 \mathrm{p} 21)$ and encodes a 463 amino acid length protein (Figure 6) [128-130]. The GLP-1R is predicted to contain a large hydrophilic $\mathrm{N}$-terminal extracellular domain with a putative signal peptide, seven hydrophobic transmembrane domains (TM1-TM7) joined by three hydrophilic ICL (ICL1, ICL2, ICL3) and three ECL (ECL1, ECL2, ECL3); ending in an intracellular C-terminal domain (Table 2) [131].

Following GLP-1 binding to the GLP-1R, the receptor undergoes a conformational change and transmits extracellular signals through heterotrimeric G-proteins (Figure 7). Heterotrimeric G-proteins are so called because they interact with Guanosine Diphosphate (GDP) and Guanosine Triphosphate (GTP) [132]. Heterotrimeric G-proteins are made up of $\alpha, \beta$, and $\gamma$ subunits and can activate or inhibit a number of effectors. The a subunit $(\mathrm{G} \alpha)$ consists of an $\alpha$-helical domain that binds guanine nucleotides, and a GTPase domain that binds and hydrolyses GTP. The Ga subunit has been categorised into four families based on similarities within their primary sequence: Gas, Gai/o, Gaq/11, Ga12/13. The $\beta$ and $\gamma$ subunits are bound in a complex (G $\beta \gamma)$ through an N-terminal coil on the $G \gamma$ subunit to the base of the $G \beta$ subunit. The G $\beta \gamma$ subunit binds to hydrophobic pocket in the Ga subunit in the inactive state [132]. Agonist-occupied GPCRs activate Ga, which dissociates from G $\beta \gamma$. The GLP-1R has been shown to activate members of the Gas, Gai/o and Gaq/11 [133,134]. Members of the Gas family activate AC, increasing cAMP levels and in turn activate both Exchange Protein Activated by cAMP (EPAC) and Protein Kinase A (PKA) [135]. Activating members of the Gai/o family inhibit AC activity and regulate inward rectifier potassium channels [136]. Gaq/11 family 
Citation: Thompson A, Kanamarlapudi V (2013) Type 2 Diabetes Mellitus and Glucagon Like Peptide-1 Receptor Signalling. Clin Exp Pharmacol 3: 138. doi:10.4172/2161-1459.1000138

Page 6 of 18

A

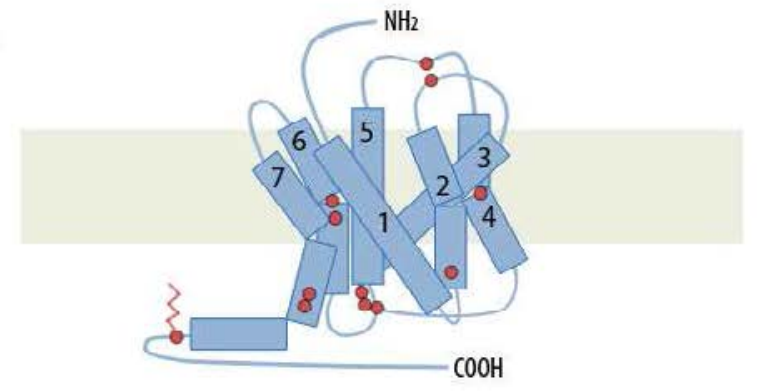

B

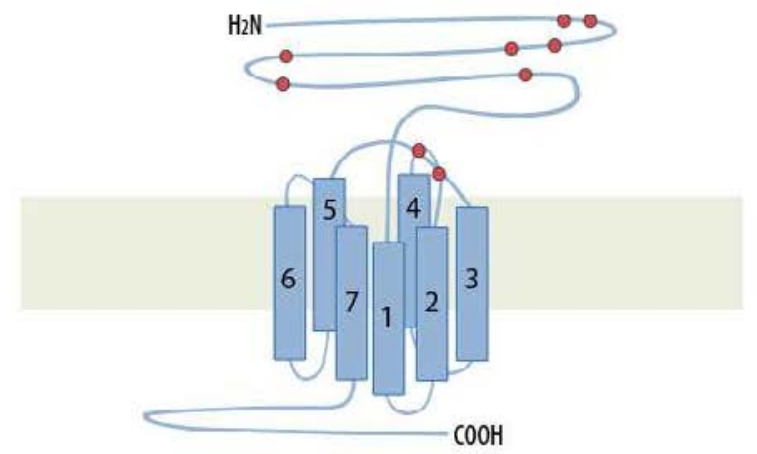

C

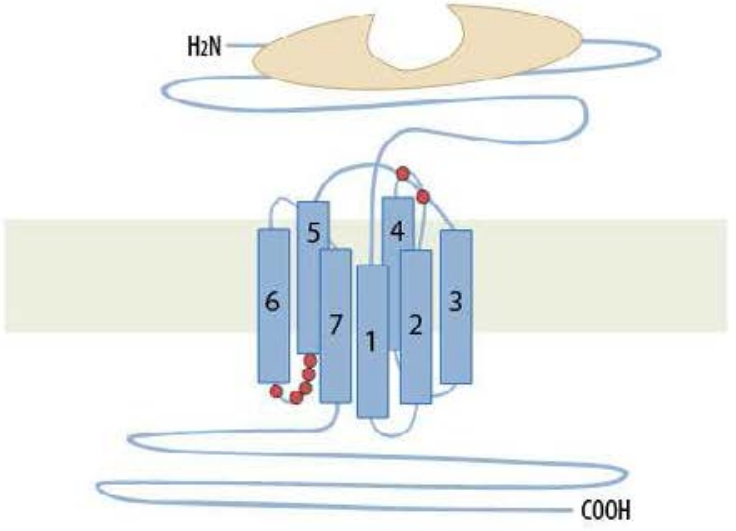

Figure 5: Structure of GPCRs. All GPCRs share a common membrane topology consisting of an NH2-terminal extracellular domain, seven transmembrane a helices joined by three ECL and ICL and an intracellular $\mathrm{COOH}$-terminal domain. Red circles denote conserved residues. (A) The Family A GPCRs contain a disulphide bridge that connects ECL1 and ECL2 causing the receptor to 'kink' and 'tilt'. The C-terminal domain contains a conserved palmitoylated cysteine residue. (B) The Family B GPCRs are characterized by a long $\mathrm{N}$-terminal tail consisting of many conserved disulphide bonds. (C) The Family C GPCRs have very large $\mathrm{N}$ and $\mathrm{C}$ - terminal domains with an agonist binding domain described as a 'venus fly trap' located at the $\mathrm{N}$ - terminus. Additionally, a conserved disulphide bridge connects ECL1 and ECL2 and a short and conserved ICL3 also define family C GPCRs. Redrawn from [246].

members activates Phospholipase C (PLC) which in turn hydrolyses phosphatidylinositol-4,5-bisphophate to Inositol-1,4,5-triphosphate (Ins(1,4,5)P3; IP3) and Diacylglycerol (DAG). DAG activates Protein Kinase C (PKC) and IP3 induces intracellular calcium release from the ER [137]. Ga12/13 family members regulate intracellular actin through Rho GTPase activity [138]. The G $\beta \gamma$ complex can also activate a number of intracellular signalling molecules and pathways including phospholipases and phosphatidylinositol 3-kinase, Ras, Raf, Extracellular signal-regulated Kinase (ERK) and ion channels, but it role in GLP-1R activation is not fully known $[136,139]$.

After stimulation with agonist, most GPCRs internalise from the cell surface to dampen the biological response, resensitisation of the system or propagation of the signal through novel transduction pathways. Agonist induced GPCR internalisation typically occurs in a clathrin-dependent fashion via GRKs (GPCR kinases), $\beta$-arrestins and ADP-ribosylation Factor (ARF) proteins (Figure 8) [140,141]. Currently, there is some confusion by which pathway the GLP-1R is internalised. It has been reported that clathrin-coated vesicles mediate GLP-1R internalisation and three PKC phosphorylation sites within the C-terminal tail are important for this to occur (Figure 6) [142]. However, more recently it has been shown that the GLP-1R is internalised by caveolae-mediated endocytosis upon agonist stimulation (Figure 9).

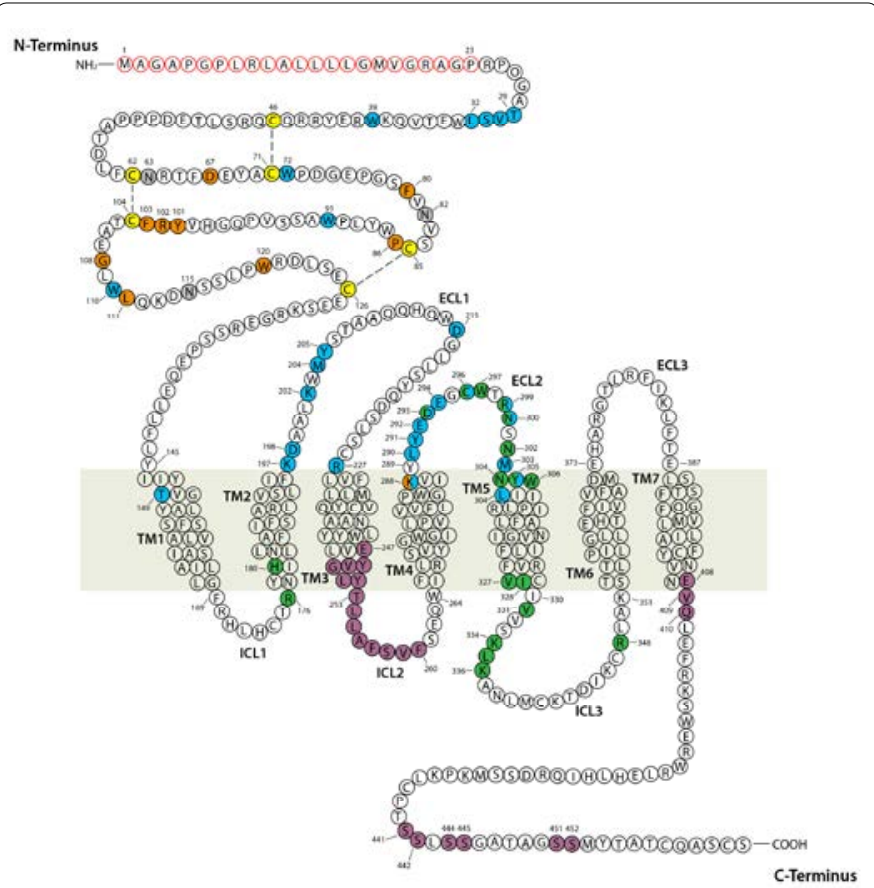

Figure 6: Amino acid Sequence of the Human GLP-1R. The signal peptide is highlighted in red circles (1-23). Residues in yellow highlight conserved cysteine residues that form disulphide bonds. Residues in blue show amino acid important in agonist binding. Amino acids that have a structural role are highlighted in orange. Glycosylation sites are shown in grey. Residues important in receptor internalization are shown in purple and for activation and functions are in green. Redrawn and adapted from [1].

\begin{tabular}{|l|l|l|l|}
\hline $\begin{array}{l}\text { Amino Acids } \\
\text { Length (from-to) }\end{array}$ & Description & $\begin{array}{l}\text { Amino Acids } \\
\text { Length (from-to) }\end{array}$ & Description \\
\hline $23(1-23)$ & Putative SP & $122(24-145)$ & NT \\
\hline $23(146-168)$ & TM1 & $8(169-176)$ & ICL1 \\
\hline $20(177-196)$ & TM2 & $31(197-227)$ & ECL1 \\
\hline $25(228-252)$ & TM3 & $12(253-264)$ & ICL2 \\
\hline $24(265-288)$ & TM4 & $15(289-303)$ & ECL2 \\
\hline $26(304-329)$ & TM5 & $22(330-351)$ & ICL3 \\
\hline $21(352-372)$ & TM6 & $15(373-387)$ & ECL3 \\
\hline $21(388-408)$ & TM7 & $55(409-463)$ & CT \\
\hline
\end{tabular}

$\mathrm{SP}=$ Signal peptide; $\mathrm{NT}=\mathrm{N}$-terminal domain; $\mathrm{CT}=\mathrm{C}$-terminal domain

Table 2: The amino acid sequence of the GLP-1R domains. 

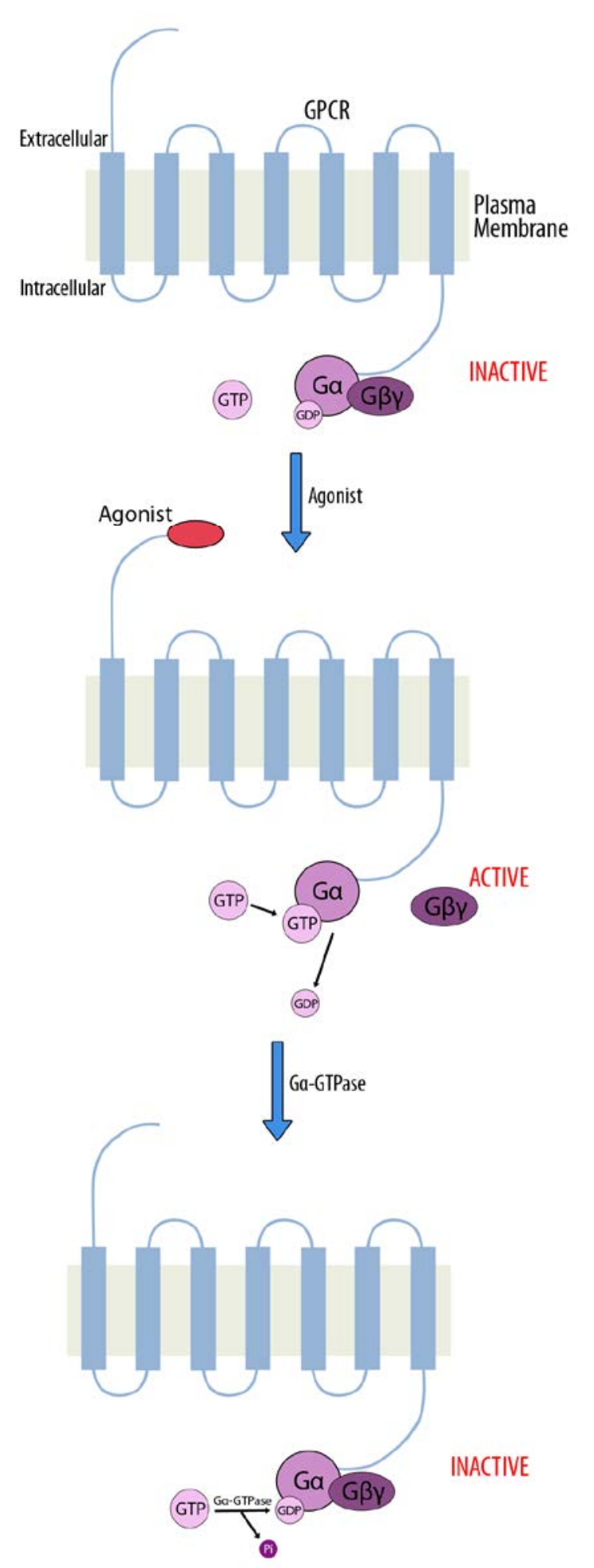

Figure 7: Activation and Inactivation of Heterotrimeric G-Proteins through GPCRs. Prior to agonist binding, the Gaßy complexes are associated with each other. GDP is bound to the Ga subunit rendering it inactive. Upon agonist binding, the Ga subunit dissociates from the GBy complex and GTP binds the $\mathrm{Ga}$ subunit, initiating signalling events. After signal transduction, GTP is hydrolyzed back to GDP by Ga-GTPase and the Ga subunit associates with the GBy complex.

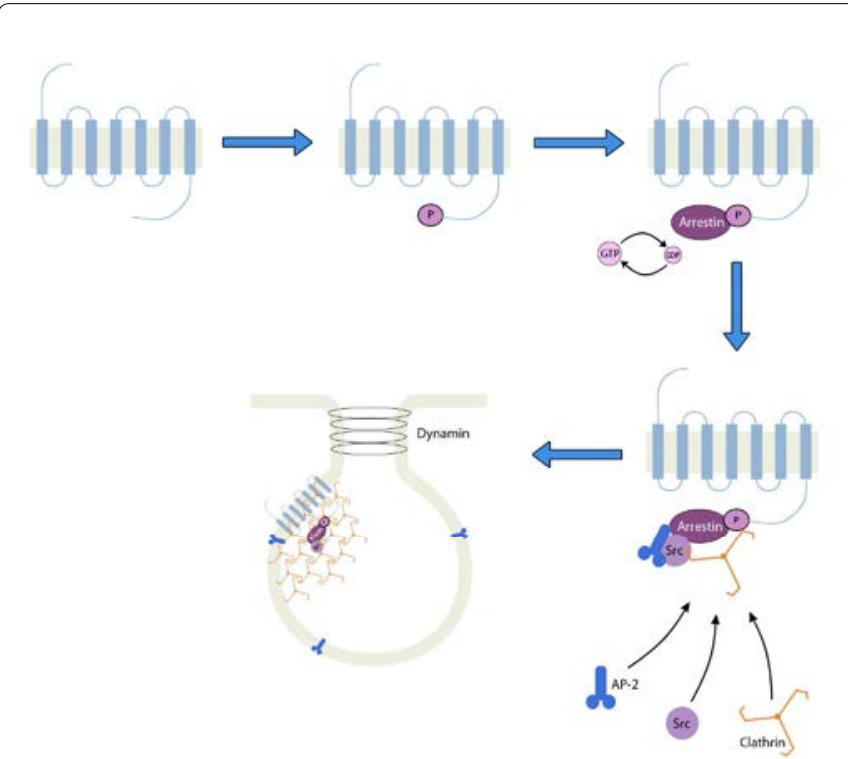

Figure 8: Clathrin-Dependent Internalisation of GPCRs. The proposed model for GPCR internalisation is based on the $\beta 2$-adrenoceptor receptor. Upon agonist binding, GPCRs are phosphorylated by GRKs, this leads to the recruitment of arrestin and subsequent ARF6 activation. The activation of ARF6 results in the promotion of clathrin, AP-2 and Src to form clathrin-coated pits. Finally, dynamin causes the 'pinching off' of vesicles from the plasma membrane into the cytosol.

A feature of GPCRs that are endocytosed via caveolae is their ability to bind caveolin-1, a protein weighing approximately $21-24 \mathrm{kDa}$. Caveolin-1 is the principle component of caveolae and can interact with a number of signalling molecules including receptor tyrosine kinases, G proteins and GPCRs. This occurs via a common caveolin-

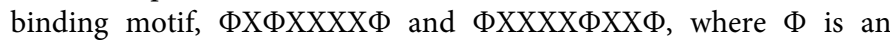
aromatic residue and $X$ is any amino acid $[143,144]$. Endocytosis in this manner can lead to fission of caveolae enriched vesicles and then fusion with caveosomes, large intermediate intracellular organelles [145]. The GLP-1R was reported to contain a classical caveolin-1 binding motif, ${ }^{247}$ EGVYLYTLLAFSVF $^{260}$, in ICL2 (Figure 6) [146].

Recently, there has been increasing interest in the stoichiometry of GPCRs and how this impacts receptor function $[147,148]$. For family B GPCRs, homodimerisation has been shown to occur with the calcitonin receptor [149)], secretin receptor [150] and parathyroid receptor [151]. There is also interest in the development of allosteric agonists and whether they interact with a single receptor (in cis) or across dimers (in trans). Currently, most drug development is dependent on an in cis conformation and mechanism of action $[152,153]$. The GLP-1R has been shown to form a homodimer through an interface along TM4 and is required for receptor signalling. Alanine substitutions to $\mathrm{Leu}^{256}$, $\mathrm{Val}^{259}$ or $\mathrm{Gly}^{252}$, Leu ${ }^{256}, \mathrm{Val}^{259}$ abolished GLP-1 binding, reduced cAMP and ERK signalling and abolished calcium signalling. Dimerisation of the GLP-1R was important for signal bias and discriminated between peptide and non-peptide activation. Additionally, dimerisation was not required for allosteric modulation by compound 2 demonstrating that this small molecule agonist acted in cis [152].

\section{Allosteric modulation of the GLP-1R}

Many GPCRs have been shown to have allosteric binding sites that are spatially and often functionally distinct to the primary agonist (orthosteric) binding site (Figure 10) [154,155]. Small molecule 


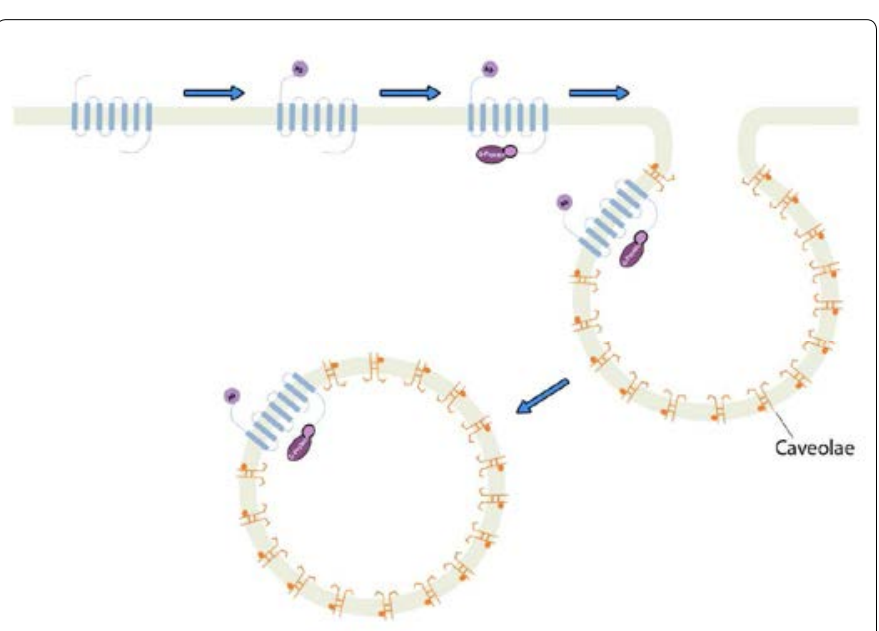

Figure 9: Caveolae-Dependent Internalisation of GPCRs. The proposed model for caveolae mediated endocytosis. Upon agonist binding a number of signaling pathways are activated. This results in the recruitment of caveolin, forming a vesicle from the plasma membrane that that enters into the cytosol.

allosteric agonists can either increase or decrease the binding efficiency of an orthosteric agonist. Such agonists are generally termed positive allosteric modulators or negative allosteric modulators depending on what effects they have on the receptor [156]. Allosteric sites may provide novel therapeutic targets and a number of advantages compared to classical orthosteric agonists. This is advantageous where selective orthosteric therapy has been difficult, for example, where the orthosteric site is highly conserved. Targeting the allosteric sites allows for greater selectivity to be obtained [157,158]. Additionally, allosteric agonists may provide a second advantage in that they can be selectively regulated by endogenous agonists [158]. Finally, low molecular weight agonists that have the potential for oral administration can be used to target allosteric binding sites [154]. Some small molecule agonists, named ago-allosteric agonists, can bind to the receptor and can act as both agonists and allosteric modulators in the absence of orthosteric agonists. It is unknown how these agonists affect the binding or efficiency of compounds acting at the orthosteric site. Compounds with allosteric or ago-allosteric properties increase the potential for receptor subtype selectivity. This allows for more improved, targeted and novel therapeutics [159]. Receptor internalisation and signalling mediated by ago-allosteric agonism may provide further information into the activation and regulation of this receptor.

A small molecule GLP-1R agonist, compound 1 (2-(2'methyl) thiadiazolylsulfanyl-3-trifluoromethyl-6,7-dichloroquinoxaline) (Figure 11A), has demonstrated low-affinity, low potency allosteric agonism to the GLP-1R. In an effort to produce a more potent agonist, compound 2 was developed (6,7-dichloro-2- methylsulfonyl-3-N-tertbutylaminoquinoxaline) (Figure 11B). Compound 2 is an ago-allosteric agonist that not only increases the affinity of GLP-1 for its receptor, but also acts as an agonist. Additionally, exendin (9-39) antagonist did not inhibit compound 2 binding, showing a second binding site on the GLP-1R distinct from the orthosteric binding site [160]. The effectiveness of compound 2 to stimulate insulin secretion has also been assessed in vivo. Although, compound 2 was able to stimulate insulin secretion it was unable to do so as effectively as GLP-1, Liraglutide or Exenatide. Further, combining compound 2 with either Liraglutide or Exenatide did not show a substantial improvement in insulin secretion response in mice [161]. Two additional small molecule agonists of the GLP-1R, compound A (4-(3,4-dichlorophenyl)-2-(ethanesulfonyl)- 6-(trifluoromethyl)pyrimidine) and compound B (4-(3-(benzyloxy) phenyl)-2-(ethylsulfinyl)-6-(trifluoromethyl)), have also demonstrated ago-allosteric properties (Figure $11 \mathrm{C}$ and $11 \mathrm{D}$ ). Like compound 2, these compounds induced cAMP signalling and increased insulin secretion in rat islets and animal studies. Further studies showed treatment with compound B to near-normalise insulin secretion with human islets isolated from a donor with type 2 diabetes [162]. These small molecule agonists indicate a useful starting point for the identification and design of orally active allosteric GLP-1R compounds.

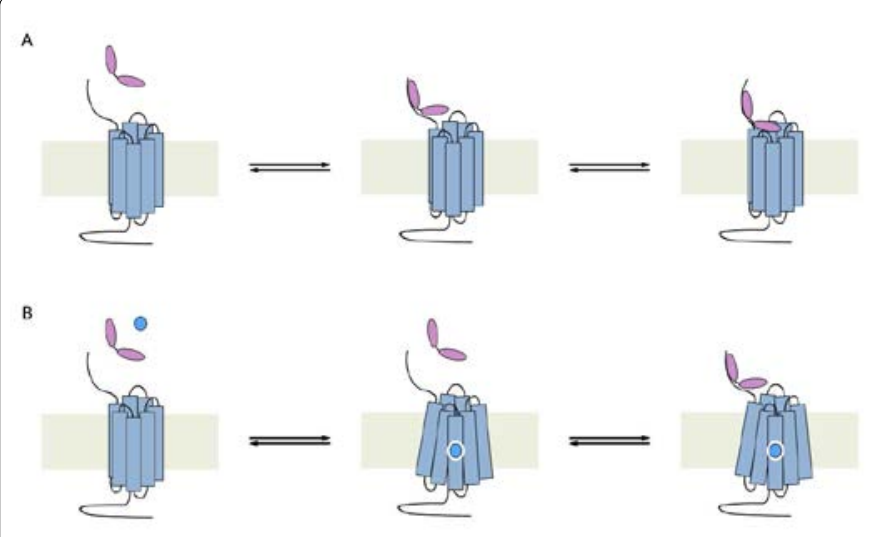

Figure 10: Binding Models of Orthosteric and Allosteric Agonists of Class B GPCRs. (A) The general peptide (orthosteric) binding model for class B GPCRs is shown. The C-terminal region of the orthosteric peptide binds to the N-terminal region of the GPCR. This results in a weak interaction and consequently causes the formation of a bi-tethered confirmation. (B) Non-peptide (allosteric) binding and antagonist model for class GPCRs. Non-peptide/ antagonist (blue circle) binds the receptor and causes a conformational change that prevents peptide binding. This non-peptide interaction can either block peptide stimulated receptor signaling or may not affect peptide binding to the N-terminal domain of the GPCR. Redrawn from [153].<smiles>Cc1nnc(Sc2nc3cc(Cl)c(Cl)cc3nc2C(F)(F)F)s1</smiles>

Compound 1<smiles>CC(C)(C)Nc1nc2cc(Cl)c(Cl)cc2nc1S(C)(=O)=O</smiles>

Compound 2
C

D<smiles>CCS(=O)(=O)c1nc(-c2ccc(Cl)cc2)cc(C(F)(F)F)n1</smiles>

Compound A<smiles>CCS(=O)c1nc(-c2cccc(OCc3ccccc3)c2)cc(C(F)(F)F)n1</smiles>

Compound B
Figure 11: Small Molecule Allosteric Agonists of the GLP-1R. The chemical structures of $(A)$ compound $1,(B)$ compound 2, (C) compound A and (D) compound $B$ are depicted. 


\section{An alternative model for agonist induced activation}

An alternative model for agonist induced activation of family $B$ GPCRs has been proposed. It has been suggested that upon binding of an orthosteric agonist to the receptor, the N-terminal domain of the receptor undergoes a conformational change and interacts with another region of the receptor, which results in GPCR activation (agonism) [163]. This hypothesis originally arose from observations with the Corticotropin-releasing Hormone Receptor (CRHR; also known as corticotropin-releasing factor receptor), another family B GPCR. Nuclear Magnetic Resonance (NMR) analysis of the CRHR showed agonist induced conformational changes where the $\mathrm{C}$-terminal region of the agonist binds the $\mathrm{N}$-terminal domain of the receptor, which in turn causes the $\mathrm{N}$-terminus to dock with the transmembrane bundle [164]. Additionally, similar conformational changes were noticed with the secretin receptor where secretin peptides with minor modifications to the $\mathrm{N}$-terminus were no longer able to interact with the receptor, but still resulted in full agonism [165]. These findings could not be explained by current agonist binding models of family B GPCRs. Further, it was shown that the synthetic peptide corresponding to a conserved sequence in the $\mathrm{N}$-terminal region of the secretin receptor, $\operatorname{Trp}^{48}-\mathrm{Asp}^{49}-\mathrm{Asn}^{50}(\mathrm{WDN})$, acts as a full agonist and docks where the top of TM6 continued onto the ICL3 in the secretin receptor [166]. This suggests that the $\mathrm{N}$-terminal domain of the secretin receptor folds to allow a 'built in agonist' to interact with the transmembrane bundle [167]. More recently, a synthetic peptide encoding an N-terminal sequence of the GLP-1R, Asn ${ }^{63}-\mathrm{Arg}^{64}-\mathrm{Thr}^{65}-\mathrm{Phe}^{66}-\mathrm{Asp}^{67}$ (NRTFD), was shown to have full agonist activity. Further, this peptide was also able to activate the secretin and vasoactive intestinal peptide type 1 receptors because it was able to form an intradomain salt bridge between side chains of arginine and aspartate in ECL3 above TM6, similar to the WDN peptide. Moreover, GLP-1 (9-37) antagonist failed to block the NRTFD action, confirming that the site of action of NRTFD peptide is different from that of endogenous agonist GLP-1 [168].

\section{The GLP-1R N-terminal domain and its signal peptide}

Approximately 15\% of GPCRs show evidence of a signal peptide sequence that is often critical for synthesis and processing of the receptor [169]. This signal peptide sequence is usually located in the $\mathrm{N}$-terminal domain of the protein. It is about 20 amino acids in length and contains a run of hydrophobic residues. The first stage of protein targeting is insertion into the ER by binding to the Signal Recognition Particle (SRP). This is usually mediated by a signal peptide sequence within the N-terminal domain of the protein [170]. Two types of signal peptide sequences can be observed. One group contains a signal peptide sequence that is cleaved by a signal peptidase and is required for ER targeting and insertion. The second group possesses a noncleavable anchor sequence within the first transmembrane domain for this process. Interestingly, the ER targeting and insertion of GPCRs can occur in either manner but the majority have a non-cleavable anchor sequence. Subsequently, the mature receptor is subjected to further post-translational modifications in the Golgi prior to translocation and insertion into the plasma membrane [171].

Cleavage of the signal peptide sequence is not essential for all GPCRs that contain them. Deleting the signal peptide sequence of the thyrotropin receptor abolished functionality $[172,173]$. However, the corticotropin-releasing factor receptor type 2a signal peptide although present, was found to be incapable of mediating ER targeting [174,175]. The GLP-1R has been shown to contain a cleavable N-terminal signal peptide that is essential for receptor processing and trafficking to the cell surface (Figure 6). A mutation to the signal peptide cleavage site
$\left(\mathrm{Ala}^{21} \mathrm{Arg}\right)$ still allowed receptor synthesis but prevented cleavage and resulted in receptor retention within the ER [176]. It is unclear why some GPCRs require a cleavable signal sequence and other do not. Statistical analysis suggests that the length of the $\mathrm{N}$-terminal domain and the number of positively charged residues it contains denotes the presence of a cleavable signal peptide sequence [171].

The GLP-1R has six highly conserved cysteine residues at the $\mathrm{N}$-terminal domain, highlighting their structural importance. These cysteine residues form disulphide bonds between $\mathrm{Cys}^{46}$ and $\mathrm{Cys}^{71}$, $\mathrm{Cys}^{62}$ and $\mathrm{Cys}^{104}$, and between $\mathrm{Cys}^{85}$ and $\mathrm{Cys}^{126}$ [177] (Figure 6). Additionally, $\mathrm{Asp}^{67}, \operatorname{Trp}^{72}, \operatorname{Pro}^{86}, \operatorname{Arg}^{102}, \mathrm{Gly}^{108}$, and $\operatorname{Trp}^{110}$ are six other residues that are highly conserved across family B GPCRs, of which $\operatorname{Trp}^{72}$ and $\operatorname{Trp}^{110}$ have been shown to be important in GLP-1R agonist binding $[1,178,179]$. The crystal structure of the GLP-1R extracellular domain has shown these conserved residues to be positioned centrally. For example, Asp ${ }^{67}$ is centrally located and forms intermolecular interactions directly with $\operatorname{Trp}^{72}$ and $\operatorname{Arg}^{121}$ and indirectly interacts with $\mathrm{Arg}^{102}$ via a water molecule. Asp ${ }^{67}$ interacts with $\mathrm{Tyr}^{69}$ and $\mathrm{Ala}^{70}$. $\operatorname{Arg}^{102}$ is sandwiched between the side chains of $\operatorname{Trp}^{72}$ and $\operatorname{Trp}^{110}$. These interactions, and $\mathrm{Gly}^{108}$, stabilise the receptors $\mathrm{N}$-terminal domain. $\mathrm{Pro}^{86}$ plays a critical role in forming the agonist binding site (Figure 6) [180]. In addition to the two highly conserved tryptophan residues, $\operatorname{Trp}^{72}$ and $\operatorname{Trp}^{110}$, already mentioned. Substitution of $\operatorname{Tr} \mathrm{P}^{39}, \operatorname{Trp}^{72}, \operatorname{Tr}^{91}$, $\operatorname{Trp}^{110}$, or $\operatorname{Trp}^{120}$ by alanine in the full-length rat GLP-1R abolished GLP-1 binding, whereas substitution of $\operatorname{Trp}^{87}$ had no effect on agonist binding [178]. The role of $\operatorname{Trp}^{33}$ still remains unclear. $\operatorname{Trp}^{120}$ has no role in agonist binding but instead plays a structural role by forming a hydrophobic cluster with $\mathrm{Phe}^{80}, \mathrm{Tyr}^{101}, \mathrm{Phe}^{103}$ and Leu ${ }^{111}$ (Figure 6) [180].

Residues $\mathrm{Thr}^{29}-\mathrm{Val}^{30}{ }^{30} \mathrm{Ser}^{31}-\mathrm{Lys}^{32}$ also located within the N-terminal domain have been shown to confer peptide specificity. A mutation to this region of the GLP-1R resulted in a 7-fold decrease in GLP-1 affinity showing its importance in agonist binding (Figure 6) [181].

\section{N-linked glycosylation of the GLP-1R}

The GLP-1R has been shown to undergo N-linked glycosylation $[182,183]$. GPCRs are synthesised in the ER and require translocation to the Golgi. In this trafficking process, GPCRs undergo post- or cotranslational modifications including glycosylation, methylation, phosphorylation, sulfation and lipid addition. It is likely that glycosylation may play an important role in cell surface trafficking and receptor maturation $[184,185]$.

$\mathrm{N}$-linked glycosylation usually occurs in the ER, which adds a glycan core unit (Glucose3-Mannose9-N-acetylglucosamine2) to an asparagine residue within a sequence of asparagine-X-serine/ threonine, where X can be any amino acid but proline [186-188]. Terminal glucose residues are cleaved by glucosidases and oligomannoses are formed (Figure 12A) [189]. During trafficking of glycoproteins from the ER to the Golgi, glycans can be extensively modified to form either complex or hybrid N-glycans (Figure 12B and C) [188,190]. Hybrid N-glycans are formed in the medial Golgi and are due to the incomplete actions of a-mannosidase II. Hybrid $\mathrm{N}$-glycans are unable to be processed to complex N-glycans [190]. O-linked glycosylation that occurs within the Golgi is not very well understood. The process involves the addition of $\mathrm{N}$-acetyl-galactosamine to serine or threonine residue and may occur at any residue with no sequence protein [191,192]. Glycans can be cleaved with the use of enzymes. PNGase F cleaves between asparagine and $\mathrm{N}$-acetylglucosamine residues on oligomannoses and both hybrid and complex $\mathrm{N}$-glycans. Endo $\mathrm{H}$ cleaves between $\mathrm{N}$-acetylglucosamine residues on oligomannoses and some hybrid glycans (Figure 12). 
O-linked glycosylation has been shown to occur in the V2 vasopressin receptor [193] and $\delta$-opioid receptor [194]. However, most GPCRs undergo N-linked glycosylation but the role of this varies between receptors. The rat GLP-1R has previously been demonstrated to undergo N-linked glycosylation [195,196]. Further, the N-terminal domain of the human GLP-1R contains three N-linked glycosylation sites at positions $\mathrm{Asn}^{63}, \mathrm{Asn}^{82}$ and $\mathrm{Asn}^{115}[182,183]$. Tunicamycin, an inhibitor of $\mathrm{N}$-linked glycosylation, interfered with GLP-1R biosynthesis and trafficking and abolished agonist binding. Further, mutations to $\mathrm{Asn}^{63}, \mathrm{Asn}^{82}$ and $\mathrm{Asn}{ }^{115}$ with leucine were made individually and in combination. Individual mutations did not affect receptor cell surface expression or agonist binding. However, mutations of two or three residues resulted in complete loss of GLP-1 binding. Immunofluorescence staining of the mutant receptors transfected cells demonstrated that the mutant receptors were still synthesised but were localised to the ER or Golgi $[182,183]$.

\section{ICLs , ECLs and TM domains of the GLP-1R}

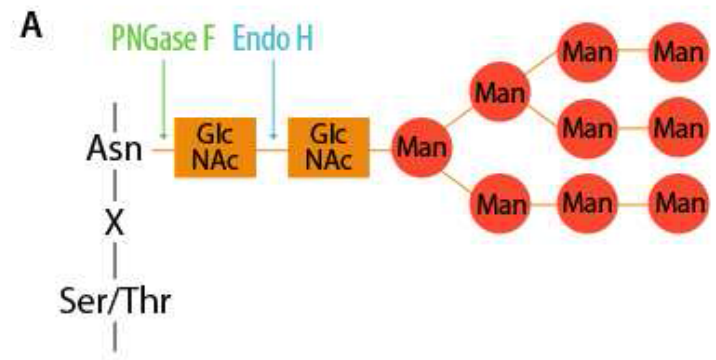

B

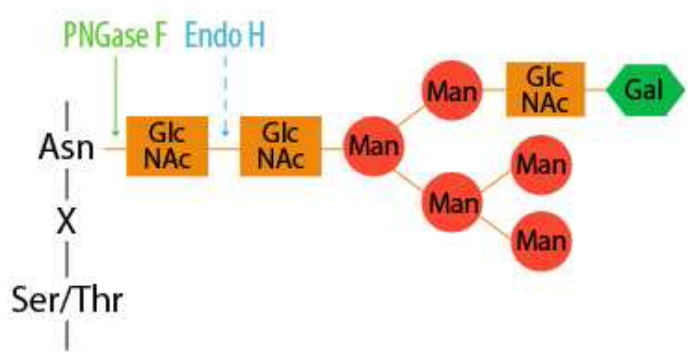

C

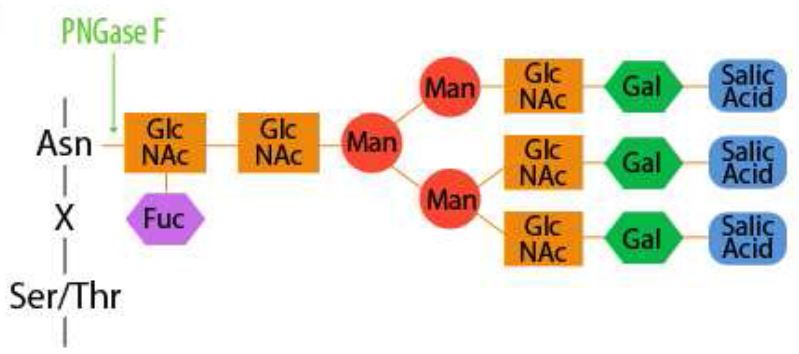

Figure 12: Structure of Common N-glycans. N-linked glycosylation at the $E R$ involves the addition of oligosaccharides to asparagine residues within a sequence of asparagine-X-serine/ threonine. (A) Terminal glucose residues are cleaved by glucosidases and oligomannoses are generated. During trafficking of glycoproteins from the ER to the Golgi, glycans can be extensively modified to form either (B) hybrid or (C) complex N-glycans. The cleavage sites of glycosidase enzymes PNGase $\mathrm{F}$ and Endo $\mathrm{H}$ are indicated. Asn= Asparagine; Fuc= Fructose; Gal= Galactose; GlcNAc= N-acetylglucosamine; Man= Mannose; Ser= Serine; Thr= Threonine; $X=$ any amino acid except proline.
The ICLs of GPCRs are known to interact with G-proteins and play a role in receptor activation [197]. For the GLP-1R, ICL3 has been shown to mediate signalling via G-proteins. However, ICL1 and ICL2 have demonstrated an importance in discriminating between different types of G-proteins. ICL1 and ICL3 specifically mediate Gas whereas ICL2 activates Gas, Gai/o and Gaq/11 [134]. An alanine substitution at $\operatorname{Arg}^{176}$ within ICL1, caused a reduction in GLP-1 mediated stimulation of cAMP but had no effect on receptor expression or internalisation (Figure 6) [198]. Additionally, different domains of ICL3 have been shown to be responsible for the Gas and Gai/o activation. The entire ICL3 (amino acids 329-351) has been shown to prefer Gas over Gai/o. However, the C-terminal end of ICL3 (amino acids 329-341) stimulates both Gas over Gai/o subtypes. Further, the N-terminal end of ICL3 (amino acids 341-351) also stimulates both subtypes, but favours Gas over Gai/o [133]. Residues important in coupling to G-proteins are mainly located in ICL3 and where TM5 meets ICL3 [199]. Alanine substitutions to $\mathrm{Val}^{327}, \mathrm{Ile}^{328}$ or $\mathrm{Val}^{331}$, where TM5 meets ICL3, caused significantly lowered cAMP production but had no effect on receptor expression (Figure 6). These residues and $\mathrm{Lys}^{334}$ form a hydrophobic face that interacts directly with the G-protein [198]. A single block deletion of $\mathrm{Lys}^{334}-\mathrm{Leu}^{335}-\mathrm{Lys}^{336}$ within the N-terminal half of ICL3 caused a significant decrease in cAMP production in response to GLP1 , of which Lys ${ }^{334}$ showed most significance with no effect on receptor expression (Figure 6). This indicated that the region was required to couple Gas and stimulate AC [199]. A glycine substitution to $\mathrm{Arg}^{348}$, near the C-terminal end of ICL3, nearly abolished cAMP production and decreased receptor affinity in response to GLP-1 (Figure 6) [200].

The ECLs of GPCRs have been shown to be important in agonist binding and receptor trafficking. A disulphide bridge between ECL1 and ECL2 is conserved across all GPCRs and has been suggested to be involved in stabilising the receptor during agonist binding [160]. Residues within TM2 and ECL1 appear to be more important in GLP-1 binding than exendin-4 binding [87,201]. Mutations within ECL1 of the GLP-1R (Lys ${ }^{197}$, Asp $^{198}$, Lys $^{202}$, Met $^{204}$, Tyr $^{205}$, Asp $^{215}$ or Arg ${ }^{227}$ ) have been shown to decrease agonist binding affinity (Figure 6) $[87,179,201]$. The GLP-1R has a number of conserved amino acids within ECL2 including $\mathrm{Lys}^{288}, \mathrm{Asp}^{293}, \mathrm{Cys}^{296}, \operatorname{Trp}^{297}$ and $\operatorname{Trp}^{306}$. These residues were demonstrated to be essential for GLP-1R function because alanine mutations resulted in a significant loss of GLP-1 binding and attenuation of receptor signalling [202,203]. Mutations within ECL2 have been shown to affect GLP-1 binding and efficiency, indicating an important role in GLP-1R activation. Interestingly, some mutations resulted in distinct changes in pathway responses. For example alanine substitutions to $\mathrm{Cys}^{296}, \operatorname{Trp}^{297}, \mathrm{Arg}^{299}, \mathrm{Asn}^{300}, \mathrm{Asn}^{302}, \mathrm{Tyr}^{305}$ and $\mathrm{Leu}^{307}$ increased signal bias towards ERK activation. However, an alanine mutation at $\operatorname{Trp}^{306}$ abolished all biological activity (Figure 6). Scanning alanine substitutions were made on ECL2 of the GLP-1R and the effect of GLP-1, exendin-4 and oxyntomodulin was assessed (Figure 6). Mutations at positions $\mathrm{Glu}^{292}$, $\mathrm{Cys}^{296}$ and $\mathrm{Asn}^{300}$ resulted in a greater potency of exendin- 4 but reduced oxyntomodulin efficacy possibly because the receptor is unable to form an active ternary complex. Met $^{303}$ appeared to play a role in cAMP signalling and was more important for exendin- 4 and oxyntomodulin than GLP-1. When positions Lys ${ }^{290}$, $\mathrm{Tyr}^{291}$ and $\mathrm{Glu}^{294}$ were mutated, a significant loss in GLP-1 calcium signalling was witnessed and no affect was seen when stimulated with oxyntomodulin. In cAMP formation, Arg ${ }^{299}$ and $\mathrm{Lys}^{307}$ mutations had a reduced potency for GLP-1 than exendin-4 suggesting exendin-4 cAMP signalling required the distal portion of ECL2. Exendin- 4 mediated calcium responses were abolished in mutations at $\mathrm{Asp}^{293}, \mathrm{Arg}^{299}, \mathrm{Tyr}^{305}$ and $\mathrm{Lys}^{307}$ yet reduced but measurable responses were observed with GLP-1 suggesting subtle difference in calcium signalling mechanisms. 
$\mathrm{Cys}^{296}, \mathrm{Arg}^{299}$ and $\mathrm{Tyr}^{305}$ mutants demonstrated no detectable calcium signalling and increased ERK signalling. Collectively, these mutations have suggested that GLP-1, exendin- 4 and oxyntomodulin activate the receptor using different mechanisms [203]. The ECL3 of the GLP-1R has originally been hypothesised to act as an endogenous agonist [166]. However, this hypothesis was disproven when it was recognised that ECL3 could not establish necessary spatial approximation with the agonist binding region of the GLP-1R [204]. The GLP-1R has recently been shown to bind an agonist peptide (NRTFD), corresponding to the sequence of the GLP-1R, $A_{s n}{ }^{63}-A_{s p}{ }^{67}$, at the N-terminal region of ECL3 $[168,205]$. Furthermore, ECL3 has been shown to be important for endogenous agonist action of several members of family B GPCRs, suggesting that this region is likely to be important for drug binding [206-208].

Residues of TM1 through to TM3 are also important for agonist binding and receptor function. For example, a missense mutation of $\mathrm{Thr}^{149}$ in TM1 reduced agonist binding [209]. Additionally, substitution of $\mathrm{His}^{180}$ by arginine in TM2 resulted in a reduction in both the potency of cAMP production and affinity of the receptor for GLP-1 (Figure 6) [200]. A positively charged Lys ${ }^{288}$ in TM4 is highly conserved in all family B GPCRs and has been demonstrated to be important for the interaction of GLP-1 to its receptor (Figure 6). Further, Lys ${ }^{288}$ has been hypothesised to be important in stabilising the top of TM4 [202]. Substitution of Lys ${ }^{288}$ by neutral leucine or alanine also reduced the affinity of GLP-1 for its receptor. However, substitution with a positively charged arginine had very little effect, demonstrating a positive charge was essential at this particular location [210]. Additionally, mutating at Lys $^{288}$ resulted in a reduced binding affinity of GLP-1 than exendin- 4 $[203,210]$. For some GPCRs such as the GLP-1R, serine and threonine rich amino acid sequences in TM3 or the cytoplasmic domain are required for receptor internalisation [142,211,212].

\section{The C-terminal tail in agonist induced internalisation}

The C-terminal domain of GPCRs is known to interact with intracellular proteins involved in receptor internalisation. There are three regions that are involved including: a region just downstream of TM7; the very end of the C-terminus; and the region in between (Figure 13) [213]. The C-terminal domain plays a critical role in agonist induced internalisation, desensitisation, down regulation and arrestin signalling [214].

The first region is called the helix- 8 and is an $\alpha$-helix that terminates with palmitoylated cysteine residues. It is located just downstream of TM7 and has been shown to associate with a number of proteins (Figure 13) [213]. For example the dopamine receptor interacting

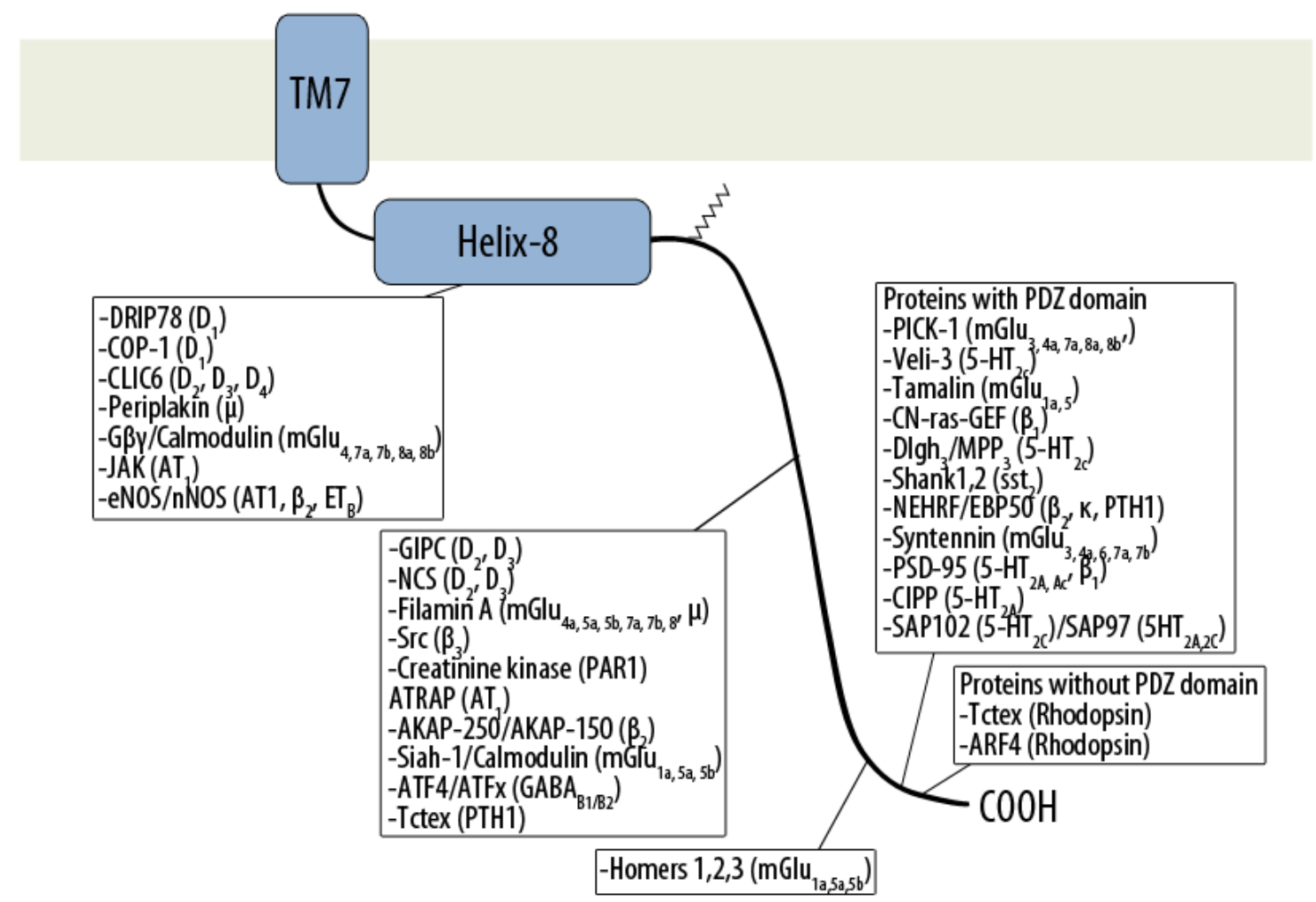

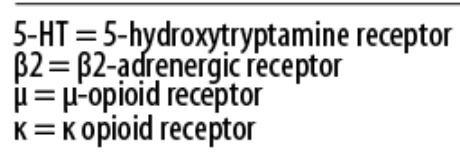

\section{AT = Angiotensin receptor \\ $\mathrm{D}=$ Dopamine receptor \\ $\mathrm{ET}=$ Endothelin \\ $\mathrm{GABA}=$ gamma-aminobutyric acid}

\section{mGlu = metabotropic glutamate receptor \\ PAR $=$ Protease activated receptor \\ PTH = Parathyroid hormone recptor \\ sst $=$ somatostain receptor}

Figure 13: Interacting Proteins of the C-terminus of GPCRs. Diagram representing the three regions of the C-terminal domain known to interact with intracellular proteins. The first region is called the helix- 8 and is an a-helix that terminates with palmitoylated cysteine residues. The second includes the PDZ domain and is located at the very end of the C-terminal domain. And the region in between that is known as 'binding sites with GPCR interacting proteins'. Redrawn from [213]. 
protein 78 binds to a conserved sequence located in the helix- 8 domain of the dopamine D1 receptor and is responsible for receptor trafficking to the plasma membrane [215].

At the very end of the C-terminal domain, many GPCRs possess a PDZ binding domain that plays a role in receptor targeting, internalisation, recycling and signalling (Figure 13) [216]. The PDZ binding domains are grouped into three classes based on their amino acid sequences $[217,218]$. GPCRs without a PDZ binding domain have shown to interact with other proteins through the extreme C-terminus. For example the C-terminus of the rhodopsin receptor was also reported to interact with ARF4 [219]. The GLP-1R lacks this PDZ binding domain. The region between helix- 8 and the very end of the C-terminus is referred to as 'binding sites with GPCR interacting proteins' (Figure 13) [213]. A PxxP motif within the C-terminus of thee $\beta 3$-adrenergic receptor interacts with the Src Homology (SH) 3 domain of Src and results in the activation of ERK [220]. In addition, the extreme of TM7 close to the C-terminal domain is also known to interact with other proteins. An NPxxY motif within the serotonin 5-hydroxytryptamine receptor 2a interacts with ARF1 and couples to phospholipase D in a G-protein independent manner [221].

GPCRs including the GLP-1R regulate intracellular effector proteins such as PLC and AC via heterotrimeric G-proteins. Upon high or sustained levels of agonist stimulation, G-protein mediated responses typically desensitise [222]. Desensitisation occurs by either an agonist specific response (homologous desensitisation) or activation of a different receptor (heterologous desensitisation). Receptor phosphorylation and arrestins mediate receptor desensitisation and cause uncoupling from G-proteins [223]. Additionally, GPCRs are phosphorylated at regions of the C-terminal domain in response to agonist binding [224]. The C-terminal domain of GPCRs is also required for targeting to endosomes, Golgi and the cell surface. These motifs are four to six amino acids in length and contain a critical tyrosine residue and follow a general consensus of $\mathrm{XX} \Phi$, where $\mathrm{Y}$ is a tyrosine residue, $\mathrm{X}$ denotes any amino acid and $\Phi$ is a hydrophobic residue [225-227].

The last 33 amino acids of the C-terminal domain of the GLP-1R containing serine $441 / 442,444 / 445$ and $451 / 452$ phosphorylation sites were required for efficient receptor activation and therefore internalisation (Figure 6) [142,228]. Interestingly, receptor internalisation was quickened when amino acids ${ }^{408} \mathrm{EVQ}^{410}$ were substituted with alanine at the $\mathrm{C}$-terminal domain of the GLP-1R [229].

\section{GLP-1R signal transduction in pancreatic $\beta$-cells}

In $\beta$-cells, the main action of GLP-1 through the GLP-1R is the formation of cAMP and its insulinotropic activity [69]. Upon agonist binding, the Gas subunit dissociates from the receptor, couples to $\mathrm{AC}$ and generates cAMP $[122,230]$. When blood glucose levels rise, it enters the $\beta$-cell through GLUT1 and GLUT2 transporters. Glucose is phosphorylated by glucokinase to glucose-6-phosphate, and results in the ATP/ ADP ratio in the cytosol increasing and the plasma membrane depolarising by closing KATP channels. The closure of KATP channels, in turn opens calcium channels, releasing intracellular stores of calcium. The increase of cytosolic calcium causes secretory granules containing insulin to fuse to the plasma membrane and insulin is exocytosed [231,232]. It is also likely that human glucokinase activity is more important in glucose-induce insulin secretion than the rate at which glucose enters the $\beta$-cell [233].

GLP-1 has been shown to increase the quantity of insulin secreted per cell and cause more $\beta$-cells to become more sensitive to increased glucose levels by GLP-1 modulated KATP channels [234,235]. Activation of GLP-1 can also increase calcium concentration by partial activation of L-type voltage dependent calcium channel and/ or increase calcium-induced calcium release from intracellular stores and is mediated by PKA phosphorylation in an ADP-dependent manner [69]. The release of intracellular stores of calcium is achieved by one of two ways: either due to PKA activation or EPAC activation $[236,237]$. It has been suggested that PKA activation is achieved through the IP3 receptor (PKA dependent) and EPAC activation is achieved through ryanodine receptors (PKA independent) [238,239].

The increase in calcium levels causes an exocytotic response and is potentiated by elevated cAMP levels due to an increase in the amount of vesicles available for release [58]. In pancreatic $\beta$-cells, there are three different pools of insulin secretory vesicles. A reserve pool is situated in the cytoplasm; a readily release pool and immediately release pool are situated close to the membrane. GLP-1 increases the amount of insulin secretory vesicles in the readily release pool. GLP-1 depolarises the cell membrane closing KATP channels and therefore the current is inactivated before the cell can begin repolarising. Consequently, the cell does not reach its resting membrane potential and starts to depolarise before it has recovered from inactivation [240].

Additionally, a sustained increase in cAMP induced nuclear translocation leads to the activation of cAMP Response Element Binding-protein (CREB) and cell proliferation. The phosphorylation of PKA is said to activate CREB, interact with Transducer of Regulated CREB activity (TORC2), increase insulin receptor substrate-1 expression and cause activation of a serine-threonine protein kinase, Akt [241]. Akt has been described to link GLP-1 signalling to $\beta$-cell growth and survival [242]. Furthermore, the activation of Ribosomal protein S6 (rbS6) in animal models has been reported as a key regulator of glucose homeostasis and $\beta$-cell mass [243].

Two mutations within the GLP-1R have been shown to alter insulin secretion. In a Japanese study, one patient diagnosed with type 2 diabetes had a missense mutation that resulted in the substitution of $\mathrm{Thr}^{149}$ with methionine [244]. The patient exhibited impaired glucose tolerance, insulin secretion and sensitivity. The mutated receptor had reduced affinity in vitro for GLP-1 and exendin-4 [209]. Further, GLP-1R mutants lacking Lys ${ }^{334}-$ Leu $^{335}-$ Lys $^{336}$ of ICL3 in the HIT-T15 insulinoma cell line showed an absence of GLP-1 induced cAMP production, calcium channel activation and insulin secretion [245].

\section{Conclusions and Future Prospects}

The ability of GLP-1 to lower postprandial hyperglycemia by increasing insulin secretion and inhibiting glucose secretion makes this peptide an ideal candidate for the treatment of type 2 diabetes. Additionally, as GLP-1 is able to retain its glucose lowering activity in patients with type 2 diabetes it is also of significant clinical relevance. The main limitation of GLP-1 is a very short half-life and as a result therapeutic strategies that activate the GLP-1R and improve GLP-1 actions have been extensively studied and developed.

GLP-1R activation by GLP-1 has many beneficial effects, most likely due to the activation of a number of signalling pathways upon agonist binding. But the precise signalling pathway that is activated and is critical for GLP-1 to exert its affects on the $\beta$-cell it still unknown. Therefore, agonists that act through the GLP-1R would be the perfect treatment in type 2 diabetes. However, only Liraglutide and Exenatide are currently available and have a number of severe side effects. As a result, there is a need for small molecule agonists that have a longer half-life and are orally active. It is also important to note that receptor- 
agonist interactions are more complex than was previously believed. Some GPCRs do not function as monomers and can be regulated by more than one agonist and can also 'self activate'. This knowledge is important for further agonist development of GPCRs. Overall a lot sill remains to be determined in GLP-1R pharmacology and drug development in the treatment of type 2 diabetes.

\section{Acknowledgements}

The work in VK's laboratory was funded by BBSRC, UK and MRC, UK. AT holds a BBSRC, UK PhD studentship. We thank members of the VK laboratory.

\section{References}

1. Doyle ME, Egan JM (2007) Mechanisms of action of glucagon-like peptide 1 in the pancreas. Pharmacol Ther 113: 546-593.

2. Holz GG, Leech CA, Heller RS, Castonguay M, Habener JF (1999) cAMPdependent mobilization of intracellular $\mathrm{Ca}+$ stores by activation of ryanodine receptors in pancreatic beta-cells. A Ca2+ signaling system stimulated by the insulinotropic hormone glucagon-like peptide-1-(7-37). J Biol Chem 274: 14147-14156.

3. Drucker DJ, Philippe J, Mojsov S, Chick WL, Habener JF (1987) Glucagon-like peptide I stimulates insulin gene expression and increases cyclic AMP levels in a rat islet cell line. Proc Natl Acad Sci U S A 84: 3434-3438.

4. Alberti KG, Zimmet PZ (1998) Definition, diagnosis and classification of diabetes mellitus and its complications. Part 1: diagnosis and classification of diabetes mellitus provisional report of a WHO consultation. Diabet Med 15: 539-553.

5. World Health Organisation. (1999) Definition, diagnosis and classification of diabetes mellitus and its complications: Report of a WHO Consultation. Part 1. Diagnosis and classification of diabetes mellitus. WHO/NCD/NCS/99.2.

6. Whiting DR, Guariguata L, Weil C, Shaw J (2011) IDF diabetes atlas: global estimates of the prevalence of diabetes for 2011 and 2030. Diabetes Res Clin Pract 94: 311-321.

7. http://www.diabetes.org.uk/Guide-to-diabetes/Introduction-to-diabetes

8. Schwarz PE, Reimann M, Li J, Bergmann A, Licinio J, et al. (2007) The Metabolic Syndrome - a global challenge for prevention. Horm Metab Res 39 777-780

9. Zimmet P, Alberti KG, Shaw J (2001) Global and societal implications of the diabetes epidemic. Nature 414: 782-787.

10. Kuzuya T, Matsuda A (1997) Classification of diabetes on the basis of etiologies versus degree of insulin deficiency. Diabetes Care 20: 219-220.

11. Rhodes CJ, White MF (2002) Molecular insights into insulin action and secretion. Eur J Clin Invest 32 Suppl 3: 3-13.

12. Nelson DL, Lehninger AL, Cox MM (2008) Lehninger principles of biochemistry. (5thedn), W. H. Freeman, New York.

13. Sadava D, Heller HC, Orians GH, Purves WK, Hillis DM (2006) Life: The Science of Biology. (8thedn), W. H. Freeman, New York.

14. Berg JM, Tymoczko JL, Stryer L (2002) Biochemistry. (5), W. H. Freeman, New York.

15. Bansal $P$, Wang $Q(2008)$ Insulin as a physiological modulator of glucagon secretion. Am J Physiol Endocrinol Metab 295: E751-761.

16. Yoon JW, Jun HS (2005) Autoimmune destruction of pancreatic beta cells. Am J Ther 12: 580-591.

17. Prentki M, Nolan CJ (2006) Islet beta cell failure in type 2 diabetes. J Clin Invest 116: $1802-1812$

18. Muoio DM, Newgard CB (2008) Mechanisms of disease: molecular and metabolic mechanisms of insulin resistance and beta-cell failure in type 2 diabetes. Nat Rev Mol Cell Biol 9: 193-205.

19. Anderson JW, Kendall CW, Jenkins DJ (2003) Importance of weight management in type 2 diabetes: review with meta-analysis of clinical studies. $J$ Am Coll Nutr 22: 331-339.

20. Eknoyan G (2008) Adolphe Quetelet (1796-1874)--the average man and indices of obesity. Nephrol Dial Transplant 23: 47-51.
21. Hollander P. (2007) Anti-Diabetes and Anti-Obesity Medications: Effects on Weight in People With Diabetes. Diabetes Spectrum 20: 159-165.

22. Cassano PA, Rosner B, Vokonas PS, Weiss ST (1992) Obesity and body fat distribution in relation to the incidence of non-insulin-dependent diabetes mellitus. A prospective cohort study of men in the normative aging study. Am J Epidemiol 136: 1474-1486.

23. Venables MC, Jeukendrup AE (2009) Physical inactivity and obesity: links with insulin resistance and type 2 diabetes mellitus. Diabetes Metab Res Rev 25 Suppl 1: S18-23.

24. Tuomilehto J, Schwarz P, Lindström J (2011) Long-term benefits from lifestyle interventions for type 2 diabetes prevention: time to expand the efforts. Diabetes Care 34 Suppl 2: S210-214.

25. Bazzano LA, Serdula M, Liu S (2005) Prevention of type 2 diabetes by diet and lifestyle modification. J Am Coll Nutr 24: 310-319.

26. Hu FB (2011) Globalization of diabetes: the role of diet, lifestyle, and genes Diabetes Care 34: 1249-1257.

27. Barnard ND, Katcher HI, Jenkins DJ, Cohen J, Turner-McGrievy G (2009) Vegetarian and vegan diets in type 2 diabetes management. Nutr Rev 67: 255263.

28. Risérus U, Willett WC, Hu FB (2009) Dietary fats and prevention of type 2 diabetes. Prog Lipid Res 48: 44-51.

29. Mozaffarian D, Kamineni A, Carnethon M, Djoussé L, Mukamal KJ, et al (2009) Lifestyle risk factors and new-onset diabetes mellitus in older adults: the cardiovascular health study. Arch Intern Med 169: 798-807.

30. Rung J, Cauchi S, Albrechtsen A, Shen L, Rocheleau G, et al. (2009) Genetic variant near IRS1 is associated with type 2 diabetes, insulin resistance and hyperinsulinemia. Nat Genet 41: 1110-1115.

31. Cooke DW, Plotnick L (2008) Type 1 diabetes mellitus in pediatrics. Pediatr Rev 29: 374-384.

32. Alba-Loureiro TC, Munhoz CD, Martins JO, Cerchiaro GA, Scavone C, et al. (2007) Neutrophil function and metabolism in individuals with diabetes mellitus. Braz J Med Biol Res 40: 1037-1044.

33. Blonde $L$ (2009) Current antihyperglycemic treatment strategies for patients with type 2 diabetes mellitus. Cleve Clin J Med 76 Suppl 5: S4-11.

34. Kitabchi AE, Nyenwe EA (2006) Hyperglycemic crises in diabetes mellitus: diabetic ketoacidosis and hyperglycemic hyperosmolar state. Endocrinol Metab Clin North Am 35: 725-751, viii.

35. Stoner GD (2005) Hyperosmolar hyperglycemic state. Am Fam Physician 71 $1723-1730$.

36. Rahbar S, Blumenfeld O, Ranney HM (1969) Studies of an unusual hemoglobin in patients with diabetes mellitus. Biochem Biophys Res Commun 36: 838-843.

37. World Health Organisation. (2011) Use of glycated haemoglobin $(\mathrm{HbA} 1 \mathrm{c})$ in the diagnosis of diabetes mellitus. WHO/NMH/CHP/CPM/11.1.

38. Creutzfeldt W, Ebert R (1985) New developments in the incretin concept Diabetologia 28: 565-573.

39. Nauck M, Stöckmann F, Ebert R, Creutzfeldt W (1986) Reduced incretin effect in type 2 (non-insulin-dependent) diabetes. Diabetologia 29: 46-52.

40. Perley MJ, Kipnis DM (1967) Plasma insulin responses to oral and intravenous glucose: studies in normal and diabetic sujbjects. J Clin Invest 46: 1954-1962.

41. Vezzosi D, Bennet A, Fauvel J, Caron P (2007) Insulin, C-peptide and proinsulin for the biochemical diagnosis of hypoglycaemia related to endogenous hyperinsulinism. Eur J Endocrinol 157: 75-83.

42. Wright EE Jr (2009) Overview of insulin replacement therapy. J Fam Pract 58 S3-9.

43. Nathan DM, Buse JB, Davidson MB, Ferrannini E, Holman RR, et al. (2009) Medical management of hyperglycemia in type 2 diabetes: a consensus algorithm for the initiation and adjustment of therapy: a consensus statement of the American Diabetes Association and the European Association for the Study of Diabetes. Diabetes Care 32: 193-203.

44. Nathan DM, Buse JB, Davidson MB, Ferrannini E, Holman RR, et al. (2008) Management of hyperglycemia in type 2 diabetes: a consensus algorithm for the initiation and adjustment of therapy: update regarding thiazolidinediones: a consensus statement from the American Diabetes Association and the European Association for the Study of Diabetes. Diabetes Care 31: 173-175. 
45. Meneghini LF (2009) Early insulin treatment in type 2 diabetes: what are the pros? Diabetes Care 32 Suppl 2: S266-269.

46. Swinnen SG, Hoekstra JB, DeVries JH (2009) Insulin therapy for type 2 diabetes. Diabetes Care 32 Suppl 2: S253-259.

47. Chiasson JL (2009) Early insulin use in type 2 diabetes: what are the cons? Diabetes Care 32 Suppl 2: S270-274.

48. Hamnvik OP, McMahon GT (2009) Balancing risk and benefit with oral hypoglycemic drugs. Mt Sinai J Med 76: 234-243.

49. Nauck MA, Vardarli I, Deacon CF, Holst JJ, Meier JJ. (2011) Secretion of glucagon-like peptide-1 (GLP-1) in type 2 diabetes: what is up, what is down? Diabetologia 54: 10-18

50. Holst JJ, Deacon CF, Vilsbøll T, Krarup T, Madsbad S (2008) Glucagon-like peptide-1, glucose homeostasis and diabetes. Trends Mol Med 14: 161-168.

51. Meier JJ, Nauck MA (2010) Is the diminished incretin effect in type 2 diabetes just an epi-phenomenon of impaired beta-cell function? Diabetes 59: 1117 1125

52. Zander M, Madsbad S, Madsen JL, Holst JJ (2002) Effect of 6-week course of glucagon-like peptide 1 on glycaemic control, insulin sensitivity, and beta-cell function in type 2 diabetes: a parallel-group study. Lancet 359: 824-830.

53. Toft-Nielsen MB, Damholt MB, Madsbad S, Hilsted LM, Hughes TE, et al. (2001) Determinants of the impaired secretion of glucagon-like peptide-1 in type 2 diabetic patients. J Clin Endocrinol Metab 86: 3717-3723.

54. Nauck MA, Heimesaat MM, Orskov C, Holst JJ, Ebert R, et al. (1993) Preserved incretin activity of glucagon-like peptide 1 [7-36 amide] but not of synthetic human gastric inhibitory polypeptide in patients with type-2 diabetes mellitus. J Clin Invest 91: 301-307.

55. Knop FK, Vilsboll T, Hojberg PV, Larsen S, Madsbad S, et al. (2007) Reduced incretin effect in type 2 diabetes: cause or consequence of the diabetic state? Diabetes 56: 1951-1959.

56. Schirra J, Katschinski M, Weidmann C, Schäfer T, Wank U, et al. (1996) Gastric emptying and release of incretin hormones after glucose ingestion in humans. J Clin Invest 97: 92-103.

57. Vilsbøll T, Krarup T, Madsbad S, Holst JJ (2002) Defective amplification of the late phase insulin response to glucose by GIP in obese Type II diabetic patients. Diabetologia 45: 1111-1119.

58. Holst JJ, Gromada J (2004) Role of incretin hormones in the regulation of insulin secretion in diabetic and nondiabetic humans. Am J Physiol Endocrinol Metab 287: E199-206.

59. Kjems LL, Holst JJ, Vølund A, Madsbad S (2003) The influence of GLP-1 on glucose-stimulated insulin secretion: effects on beta-cell sensitivity in type 2 and nondiabetic subjects. Diabetes 52: 380-386.

60. Nyholm B, Walker M, Gravholt CH, Shearing PA, Sturis J, et al. (1999) Twentyfour-hour insulin secretion rates, circulating concentrations of fuel substrates and gut incretin hormones in healthy offspring of Type II (non-insulin-dependent) diabetic parents: evidence of several aberrations. Diabetologia 42: 1314-1323.

61. Nauck MA, El-Ouaghlidi A, Gabrys B, Hücking K, Holst JJ, et al. (2004) Secretion of incretin hormones (GIP and GLP-1) and incretin effect after ora glucose in first-degree relatives of patients with type 2 diabetes. Regul Pept 122: 209-217.

62. Holst JJ, Vilsbøll T, Deacon CF (2009) The incretin system and its role in type 2 diabetes mellitus. Mol Cell Endocrinol 297: 127-136.

63. Salehi M, Aulinger B, Prigeon RL, D'Alessio DA (2010) Effect of endogenous GLP-1 on insulin secretion in type 2 diabetes. Diabetes 59: 1330-1337.

64. Nauck MA, Ratner RE, Kapitza C, Berria R, Boldrin M, et al. (2009) Treatment with the human once-weekly glucagon-like peptide-1 analog taspoglutide in combination with metformin improves glycemic control and lowers body weight in patients with type 2 diabetes inadequately controlled with metformin alone: a double-blind placebo-controlled study. Diabetes Care 32: 1237-1243.

65. Ratner R, Nauck M, Kapitza C, Asnaghi V, Boldrin M, et al. (2010) Safety and tolerability of high doses of taspoglutide, a once-weekly human GLP-1 analogue, in diabetic patients treated with metformin: a randomized doubleblind placebo-controlled study. Diabet Med 27: 556-562.

66. Gallwitz B (2010) The evolving place of incretin-based therapies in type 2 diabetes. Pediatr Nephrol 25: 1207-1217.
67. Dhanvantari S, Izzo A, Jansen E, Brubaker PL (2001) Coregulation of glucagonlike peptide-1 synthesis with proglucagon and prohormone convertase 1 gene expression in enteroendocrine GLUTag cells. Endocrinology 142: 37-42.

68. Mojsov S, Heinrich G, Wilson IB, Ravazzola M, Orci L, et al. (1986) Preproglucagon gene expression in pancreas and intestine diversifies at the level of post-translational processing. J Biol Chem 261: 11880-11889.

69. Holst JJ (2007) The physiology of glucagon-like peptide 1. Physiol Rev 87 1409-1439.

70. Orskov C, Holst JJ, Knuhtsen S, Baldissera FG, Poulsen SS, et al. (1986) Glucagon-like peptides GLP-1 and GLP-2, predicted products of the glucagon gene, are secreted separately from pig small intestine but not pancreas. Endocrinology 119: 1467-1475.

71. Orskov C, Holst JJ, Poulsen SS, Kirkegaard P (1987) Pancreatic and intestina processing of proglucagon in man. Diabetologia 30: 874-881.

72. Rouille Y, Westermark G, Martin SK, Steiner DF. (1994) Proglucagon is processed to glucagon by prohormone convertase PC2 in alpha TC1-6 cells. Proc Natl Acad Sci U S A 91: 3242-3246.

73. Baggio LL, Drucker DJ (2004) Clinical endocrinology and metabolism. Glucagon-like peptide-1 and glucagon-like peptide-2. Best Pract Res Clin Endocrinol Metab 18: 531-554.

74. Orskov C, Bersani M, Johnsen AH, Højrup P, Holst JJ (1989) Complete sequences of glucagon-like peptide-1 from human and pig small intestine. $J$ Biol Chem 264: 12826-12829.

75. Thomas L, Leduc R, Thorne BA, Smeekens SP, Steiner DF, et al. (1991) Kex2 like endoproteases PC2 and PC3 accurately cleave a model prohormone in mammalian cells: evidence for a common core of neuroendocrine processing enzymes. Proc Natl Acad Sci U S A 88: 5297-5301.

76. Wideman RD, Yu IL, Webber TD, Verchere CB, Johnson JD, et al. (2006) Improving function and survival of pancreatic islets by endogenous production of glucagon-like peptide 1 (GLP-1). Proc Natl Acad Sci U S A 103: 1346813473.

77. Wideman RD, Covey SD, Webb GC, Drucker DJ, Kieffer TJ (2007) A switch from prohormone convertase (PC)-2 to $\mathrm{PC} 1 / 3$ expression in transplanted alpha-cells is accompanied by differential processing of proglucagon and improved glucose homeostasis in mice. Diabetes 56: 2744-2752.

78. Wideman RD, Gray SL, Covey SD, Webb GC, Kieffer TJ (2009) Transplantation of PC1/3-Expressing alpha-cells improves glucose handling and cold tolerance in leptin-resistant mice. Mol Ther 17: 191-198.

79. Vahl TP, Paty BW, Fuller BD, Prigeon RL, D'Alessio DA (2003) Effects of GLP1-(7-36)NH2, GLP-1-(7-37), and GLP-1- (9-36)NH2 on intravenous glucose tolerance and glucose-induced insulin secretion in healthy humans. J Clin Endocrinol Metab 88: 1772-1779.

80. Orskov C, Wettergren A, Holst JJ (1993) Biological effects and metabolic rates of glucagonlike peptide-1 7-36 amide and glucagonlike peptide-1 7-37 in healthy subjects are indistinguishable. Diabetes 42: 658-661.

81. Nyström T (2008) The potential beneficial role of glucagon-like peptide-1 in endothelial dysfunction and heart failure associated with insulin resistance. Horm Metab Res 40: 593-606.

82. Hansen L, Deacon CF, Orskov C, Holst JJ. (1999) Glucagon-like peptide-1-(7-36)amide is transformed to glucagon-like peptide-1-(9-36)amide by dipeptidyl peptidase IV in the capillaries supplying the $L$ cells of the porcine intestine. Endocrinology 140: 5356-5363.

83. Larsen J, Hylleberg B, Ng K, Damsbo P (2001) Glucagon-like peptide-1 infusion must be maintained for $24 \mathrm{~h} /$ day to obtain acceptable glycemia in type 2 diabetic patients who are poorly controlled on sulphonylurea treatment Diabetes Care 24: 1416-1421.

84. Mentlein $R$ (2009) Mechanisms underlying the rapid degradation and elimination of the incretin hormones GLP-1 and GIP. Best Pract Res Clin Endocrinol Metab 23: 443-452.

85. Vilsbøll T, Agersø H, Krarup T, Holst JJ (2003) Similar elimination rates of glucagon-like peptide-1 in obese type 2 diabetic patients and healthy subjects. $\mathrm{J}$ Clin Endocrinol Metab 88: 220-224

86. Kieffer TJ, Mclntosh CH, Pederson RA (1995) Degradation of glucosedependent insulinotropic polypeptide and truncated glucagon-like peptide 1 in vitro and in vivo by dipeptidyl peptidase IV. Endocrinology 136: 3585-3596. 
87. López de Maturana R, Donnelly D (2002) The glucagon-like peptide-1 receptor binding site for the N-terminus of GLP-1 requires polarity at Asp198 rather than negative charge. FEBS Lett 530: 244-248.

88. Montrose-Rafizadeh C, Yang H, Rodgers BD, Beday A, Pritchette LA, et al. (1997) High potency antagonists of the pancreatic glucagon-like peptide-1 receptor. J Biol Chem 272: 21201-21206.

89. Reimann F (2010) Molecular mechanisms underlying nutrient detection by incretin-secreting cells. Int Dairy J 20: 236-242.

90. Abu-Hamdah R, Rabiee A, Meneilly GS, Shannon RP, Andersen DK, et al (2009) Clinical review: The extrapancreatic effects of glucagon-like peptide-1 and related peptides. J Clin Endocrinol Metab 94: 1843-1852.

91. De León DD, Crutchlow MF, Ham JY, Stoffers DA (2006) Role of glucagon-like peptide- 1 in the pathogenesis and treatment of diabetes mellitus. Int J Biochem Cell Biol 38: 845-859.

92. Wei Y, Mojsov S (1995) Tissue-specific expression of the human recepto for glucagon-like peptide-l: brain, heart and pancreatic forms have the same deduced amino acid sequences. FEBS Lett 358: 219-224

93. Bullock BP, Heller RS, Habener JF (1996) Tissue distribution of messenger ribonucleic acid encoding the rat glucagon-like peptide-1 receptor Endocrinology 137: 2968-2978.

94. Gupta NA, Mells J, Dunham RM, Grakoui A, Handy J, et al. (2010) Glucagonlike peptide-1 receptor is present on human hepatocytes and has a direct role in decreasing hepatic steatosis in vitro by modulating elements of the insulin signaling pathway. Hepatology 51: 1584-1592.

95. Rayner CK, Samsom M, Jones KL, Horowitz M (2001) Relationships of upper gastrointestinal motor and sensory function with glycemic control. Diabetes Care 24: 371-381.

96. De Marinis YZ, Salehi A, Ward CE, Zhang Q, Abdulkader F, et al. (2010) GLP-1 inhibits and adrenaline stimulates glucagon release by differential modulation of N- and L-type Ca2+ channel-dependent exocytosis. Cell Metab 11: 543-553.

97. Li L, El-Kholy W, Rhodes CJ, Brubaker PL (2005) Glucagon-like peptide-1 protects beta cells from cytokine-induced apoptosis and necrosis: role of protein kinase B. Diabetologia 48: 1339-1349.

98. Cunha DA, Ladrière L, Ortis F, Igoillo-Esteve M, Gurzov EN, et al. (2009) Glucagon-like peptide-1 agonists protect pancreatic beta-cells from lipotoxic endoplasmic reticulum stress through upregulation of BiP and JunB. Diabetes 58: 2851-2862.

99. Quoyer J, Longuet C, Broca C, Linck N, Costes S, et al. (2010) GLP-1 mediates antiapoptotic effect by phosphorylating Bad through a beta-arrestin 1-mediated ERK1/2 activation in pancreatic beta-cells. J Biol Chem 285: 1989-2002.

100. Kim DH, D'Alessio DA, Woods SC, Seeley RJ (2009) The effects of GLP-1 infusion in the hepatic portal region on food intake. Regul Pept 155: 110-114.

101. Hayes MR (2012) Neuronal and intracellular signaling pathways mediating GLP-1 energy balance and glycemic effects. Physiol Behav 106: 413-416.

102. Hayes MR, Bradley L, Grill HJ (2009) Endogenous hindbrain glucagon-like peptide-1 receptor activation contributes to the control of food intake by mediating gastric satiation signaling. Endocrinology 150: 2654-2659.

103. Burcelin R, Serino M, Cabou C (2009) A role for the gut-to-brain GLP-1 dependent axis in the control of metabolism. Curr Opin Pharmacol 9: 744-752.

104. Grieve DJ, Cassidy RS, Green BD (2009) Emerging cardiovascular actions of the incretin hormone glucagon-like peptide-1: potential therapeutic benefits beyond glycaemic control? Br J Pharmacol 157: 1340-1351.

105. Tomas E, Habener JF (2010) Insulin-like actions of glucagon-like peptide-1: a dual receptor hypothesis. Trends Endocrinol Metab 21: 59-67.

106. Charbonnel B, Karasik A, Liu J, Wu M, Meininger G; Sitagliptin Study 020 Group (2006) Efficacy and safety of the dipeptidyl peptidase-4 inhibitor sitagliptin added to ongoing metformin therapy in patients with type 2 diabetes inadequately controlled with metformin alone. Diabetes Care 29: 2638-2643.

107. Khunti K, Davies M (2010) Glycaemic goals in patients with type 2 diabetes: current status, challenges and recent advances. Diabetes Obes Metab 12: 474-484.

108. Gilbert MP, Pratley RE. (2009) Efficacy and safety of incretin-based therapies in patients with type 2 diabetes mellitus. Am J Med 122: S11-24.

109. Deacon CF, Holst JJ (2006) Dipeptidyl peptidase IV inhibitors: a promising new therapeutic approach for the management of type 2 diabetes. Int $J$ Biochem Cell Biol 38: 831-844.

110. Yu DM, Yao TW, Chowdhury S, Nadvi NA, Osborne B, et al. (2010) The dipeptidyl peptidase IV family in cancer and cell biology. FEBS J 277: 11261144.

111. Stulc T, Sedo A (2010) Inhibition of multifunctional dipeptidyl peptidase-IV: is there a risk of oncological and immunological adverse effects? Diabetes Res Clin Pract 88: 125-131.

112. Deacon CF, Knudsen LB, Madsen K, Wiberg FC, Jacobsen O, et al. (1998) Dipeptidyl peptidase IV resistant analogues of glucagon-like peptide-1 which have extended metabolic stability and improved biological activity. Diabetologia 41: 271-278.

113. Edavalath M, Stephens JW (2010) Liraglutide in the treatment of type 2 diabetes mellitus: clinical utility and patient perspectives. Patient Prefe Adherence 4: 61-68.

114. González C, Beruto V, Keller G, Santoro S, Di Girolamo G (2006) Investigationa treatments for Type 2 diabetes mellitus: exenatide and liraglutide. Expert Opin Investig Drugs 15: 887-895.

115. Pinkney J, Fox T, Ranganath L (2010) Selecting GLP-1 agonists in the management of type 2 diabetes: differential pharmacology and therapeutic benefits of liraglutide and exenatide. Ther Clin Risk Manag 6: 401-411.

116. Eng J, Kleinman WA, Singh L, Singh G, Raufman JP (1992) Isolation and characterization of exendin-4, an exendin-3 analogue, from Heloderma suspectum venom. Further evidence for an exendin receptor on dispersed acini from guinea pig pancreas. J Biol Chem 267: 7402-7405.

117. Gallwitz B (2006) Exenatide in type 2 diabetes: treatment effects in clinical studies and animal study data. Int J Clin Pract 60: 1654-1661.

118. Bond A (2006) Exenatide (Byetta) as a novel treatment option for type 2 diabetes mellitus. Proc (Bayl Univ Med Cent) 19: 281-284.

119. Kim Chung le T, Hosaka T, Yoshida M, Harada N, Sakaue H, et al. (2009) Exendin-4, a GLP-1 receptor agonist, directly induces adiponectin expression through protein kinase A pathway and prevents inflammatory adipokine expression. Biochem Biophys Res Commun 390: 613-618.

120.Buse JB, Rosenstock J, Sesti G, Schmidt WE, Montanya E, et al. (2009) Liraglutide once a day versus exenatide twice a day for type 2 diabetes: a 26-week randomised, parallel-group, multinational, open-label trial (LEAD-6) Lancet 374: 39-47.

121. Drucker DJ, Sherman SI, Gorelick FS, Bergenstal RM, Sherwin RS, et al (2010) Incretin-based therapies for the treatment of type 2 diabetes: evaluation of the risks and benefits. Diabetes Care 33: 428-433.

122. Coopman K, Huang Y, Johnston N, Bradley SJ, Wilkinson GF, et al. (2010) Comparative effects of the endogenous agonist glucagon-like peptide-1 (GLP1)-(7-36) amide and the small-molecule ago-allosteric agent "compound 2 " at the GLP-1 receptor. J Pharmacol Exp Ther 334: 795-808.

123. Haque TS, Lee VG, Riexinger D, Lei M, Malmstrom S, et al. (2010) Identification of potent $11 \mathrm{mer}$ glucagon-like peptide-1 receptor agonist peptides with nove C-terminal amino acids: Homohomophenylalanine analogs. Peptides 31: 950955.

124. Mapelli C, Natarajan SI, Meyer JP, Bastos MM, Bernatowicz MS, et al. (2009) Eleven amino acid glucagon-like peptide-1 receptor agonists with antidiabetic activity. J Med Chem 52: 7788-7799.

125. Millar RP, Newton CL (2010) The year in G protein-coupled receptor research. Mol Endocrinol 24: 261-274

126. Kristiansen K. (2004) Molecular mechanisms of ligand binding, signaling, and regulation within the superfamily of G-protein-coupled receptors: molecula modeling and mutagenesis approaches to receptor structure and function. Pharmacol Ther 103: 21-80.

127. Parthier C, Reedtz-Runge S, Rudolph R, Stubbs MT (2009) Passing the baton in class B GPCRs: peptide hormone activation via helix induction? Trends Biochem Sci 34: 303-310.

128. van Eyll B, Lankat-Buttgereit B, Bode HP, Göke R, Göke B (1994) Signal transduction of the GLP-1-receptor cloned from a human insulinoma. FEBS Lett 348: 7-13.

129. Stoffel M, Espinosa R 3rd, Le Beau MM, Bell GI (1993) Human glucagonlike peptide-1 receptor gene. Localization to chromosome band $6 \mathrm{p} 21$ by fluorescence in situ hybridization and linkage of a highly polymorphic simple 
tandem repeat DNA polymorphism to other markers on chromosome 6 . Diabetes 42: 1215-1218.

130. Brubaker PL, Drucker DJ (2002) Structure-function of the glucagon receptor family of $\mathrm{G}$ protein-coupled receptors: the glucagon, GIP, GLP-1, and GLP-2 receptors. Receptors Channels 8: 179-188.

131.Palczewski K. (2000) Crystal Structure of Rhodopsin: A G Protein-Coupled Receptor. Science 289: 739-745.

132. Cabrera-Vera TM, Vanhauwe J, Thomas TO, Medkova M, Preininger A, et al. (2003) Insights into $G$ protein structure, function, and regulation. Endocr Rev 24: 765-781.

133. Hällbrink M, Holmqvist T, Olsson M, Ostenson CG, Efendic S, et al. (2001) Different domains in the third intracellular loop of the GLP-1 receptor are responsible for Galpha(s) and Galpha(i)/Galpha(o) activation. Biochim Biophys Acta 1546: 79-86.

134. Bavec A, Hällbrink M, Langel U, Zorko M (2003) Different role of intracellular loops of glucagon-like peptide-1 receptor in G-protein coupling. Regul Pept 111: $137-144$.

135. Bos JL (2003) Epac: a new cAMP target and new avenues in cAMP research. Nat Rev Mol Cell Biol 4: 733-738.

136. Vilardaga JP, Bünemann M, Feinstein TN, Lambert N, Nikolaev VO, et al. (2009) GPCR and G proteins: drug efficacy and activation in live cells. Mol Endocrinol 23: 590-599.

137. Werry TD, Wilkinson GF, Willars GB (2003) Mechanisms of cross-talk between G-protein-coupled receptors resulting in enhanced release of intracellular Ca2+. Biochem J 374: 281-296.

138. Heasman SJ, Ridley AJ (2008) Mammalian Rho GTPases: new insights into their functions from in vivo studies. Nat Rev Mol Cell Biol 9: 690-701.

139. Jacoby E, Bouhelal R, Gerspacher M, Seuwen K (2006) The 7 TM G-proteincoupled receptor target family. ChemMedChem 1: 761-782.

140.Luttrell LM, Lefkowitz RJ (2002) The role of beta-arrestins in the termination and transduction of G-protein-coupled receptor signals. J Cell Sci 115: 455465.

141. Kanamarlapudi V, Thompson A, Kelly E, López Bernal A (2012) ARF6 activated by the LHCG receptor through the cytohesin family of guanine nucleotide exchange factors mediates the receptor internalization and signaling. J Biol Chem 287: 20443-20455.

142. Widmann C, Dolci W, Thorens B (1997) Internalization and homologous desensitization of the GLP-1 receptor depend on phosphorylation of the receptor carboxyl tail at the same three sites. Mol Endocrinol 11: 1094-1102.

143. Couet J, Li S, Okamoto T, Ikezu T, Lisanti MP (1997) Identification of peptide and protein ligands for the caveolin-scaffolding domain. Implications for the interaction of caveolin with caveolae-associated proteins. J Biol Chem 272 : 6525-6533.

144. Okamoto T, Schlegel A, Scherer PE, Lisanti MP. (1998) Caveolins, a family of scaffolding proteins for organizing "preassembled signaling complexes" at the plasma membrane". Journal of Biological Chemistry 273: 5419-5422.

145. Pelkmans L, Kartenbeck J, Helenius A (2001) Caveolar endocytosis of simian virus 40 reveals a new two-step vesicular-transport pathway to the ER. Nat Cell Biol 3: 473-483.

146. Syme CA, Zhang L, Bisello A (2006) Caveolin-1 regulates cellular trafficking and function of the glucagon-like Peptide 1 receptor. Mol Endocrinol 20: 34003411.

147. Casadó V, Cortés A, Mallol J, Pérez-Capote K, Ferré S, et al. (2009) GPCR homomers and heteromers: a better choice as targets for drug development than GPCR monomers? Pharmacol Ther 124: 248-257.

148. Milligan $G$ (2009) G protein-coupled receptor hetero-dimerization: contribution to pharmacology and function. Br J Pharmacol 158: 5-14.

149. Harikumar KG, Ball AM, Sexton PM, Miller LJ (2010) Importance of lipidexposed residues in transmembrane segment four for family B calcitonin receptor homo-dimerization. Regul Pept 164: 113-119.

150. Harikumar KG, Pinon DI, Miller LJ (2007) Transmembrane segment IV contributes a functionally important interface for oligomerization of the Class II G protein-coupled secretin receptor. J Biol Chem 282: 30363-30372.

151.Pioszak AA, Harikumar KG, Parker NR, Miller LJ, Xu HE (2010) Dimeric arrangement of the parathyroid hormone receptor and a structural mechanism for ligand-induced dissociation. J Biol Chem 285: 12435-12444.

152. Harikumar KG, Wootten D, Pinon DI, Koole C, Ball AM, et al. (2012) Glucagonlike peptide-1 receptor dimerization differentially regulates agonist signaling but does not affect small molecule allostery. Proc Natl Acad Sci U S A 109: 18607-18612.

153. Hoare SR (2007) Allosteric modulators of class B G-protein-coupled receptors. Curr Neuropharmacol 5: 168-179.

154.Schwartz TW, Holst B (2007) Allosteric enhancers, allosteric agonists and ago-allosteric modulators: where do they bind and how do they act? Trends Pharmacol Sci 28: 366-373.

155. Wang L, Martin B, Brenneman R, Luttrell LM, Maudsley S (2009) Allosteric modulators of $\mathrm{g}$ protein-coupled receptors: future therapeutics for complex physiological disorders. J Pharmacol Exp Ther 331: 340-348.

156. De Amici M, Dallanoce C, Holzgrabe U, Tränkle C, Mohr K (2010) Allosteric ligands for $G$ protein-coupled receptors: a novel strategy with attractive therapeutic opportunities. Med Res Rev 30: 463-549.

157. Urban JD, Clarke WP, von Zastrow M, Nichols DE, Kobilka B, et al. (2007) Functional selectivity and classical concepts of quantitative pharmacology. $J$ Pharmacol Exp Ther 320: 1-13.

158. Kenakin TP (2009) '7TM receptor allostery: putting numbers to shapeshifting proteins. Trends Pharmacol Sci 30: 460-469.

159. Bridges TM, Lindsley CW (2008) G-protein-coupled receptors: from classical modes of modulation to allosteric mechanisms. ACS Chem Biol 3: 530-541.

160. Knudsen LB, Kiel D, Teng M, Behrens C, Bhumralkar D, et al. (2007) Smallmolecule agonists for the glucagon-like peptide 1 receptor. Proc Natl Acad Sci U S A 104: 937-942.

161. Irwin N, Flatt PR, Patterson S, Green BD (2010) Insulin-releasing and metabolic effects of small molecule GLP-1 receptor agonist 6,7-dichloro-2methylsulfonyl-3-N-tert-butylaminoquinoxaline. Eur J Pharmacol 628: 268273.

162. Sloop KW, Willard FS, Brenner MB, Ficorilli J, Valasek K, et al. (2010) Nove small molecule glucagon-like peptide-1 receptor agonist stimulates insulin secretion in rodents and from human islets. Diabetes 59: 3099-3107.

163. Beinborn M (2006) Class B GPCRs: a hidden agonist within? Mol Pharmacol 70: $1-4$.

164. Grace CR, Perrin MH, DiGruccio MR, Miller CL, Rivier JE, et al. (2004) NMR structure and peptide hormone binding site of the first extracellular domain of a type B1 G protein-coupled receptor. Proc Natl Acad Sci U S A 101: 1283612841

165. Dong M, Pinon DI, Miller LJ (2005) Insights into the structure and molecular basis of ligand docking to the $G$ protein-coupled secretin receptor using charge-modified amino-terminal agonist probes. Mol Endocrinol 19: 18211836 .

166. Dong M, Pinon DI, Asmann YW, Miller LJ (2006) Possible endogenous agonist mechanism for the activation of secretin family $G$ protein-coupled receptors. Mol Pharmacol 70: 206-213.

167. Gether U (2000) Uncovering molecular mechanisms involved in activation of $G$ protein-coupled receptors. Endocr Rev 21: 90-113.

168. Dong M, Gao F, Pinon DI, Miller LJ (2008) Insights into the structural basis of endogenous agonist activation of family B G protein-coupled receptors. Mol Endocrinol 22: 1489-1499.

169. Köchl R, Alken M, Rutz C, Krause G, Oksche A, et al. (2002) The signa peptide of the $G$ protein-coupled human endothelin $B$ receptor is necessary for translocation of the $\mathrm{N}$-terminal tail across the endoplasmic reticulum membrane. J Biol Chem 277: 16131-16138.

170. Hegde RS, Lingappa VR (1997) Membrane protein biogenesis: regulated complexity at the endoplasmic reticulum. Cell $91: 575-582$

171. Wallin E, von Heijne G (1995) Properties of N-terminal tails in G-protein coupled receptors: a statistical study. Protein Eng 8: 693-698.

172. Ban T, Kosugi S, Kohn LD. (1992) Specific antibody to the thyrotropin receptor identifies multiple receptor forms in membranes of cells transfected with wild-type receptor complementary deoxyribonucleic acid: characterization of their relevance to receptor synthesis, processing, structure, and function. 


\section{Endocrinology 131: 815-829.}

173. Akamizu T, Kosugi S, Kohn LD (1990) Thyrotropin receptor processing and interaction with thyrotropin. Biochem Biophys Res Commun 169: 947-952.

174. Schulz K, Rutz C, Westendorf C, Ridelis I, Vogelbein S, et al. (2010) The pseudo signal peptide of the corticotropin-releasing factor receptor type $2 a$ decreases receptor expression and prevents Gi-mediated inhibition of adenylyl cyclase activity. J Biol Chem 285: 32878-32887.

175. Rutz C, Renner A, Alken M, Schulz K, Beyermann M, et al. (2006) The corticotropin-releasing factor receptor type 2a contains an $\mathrm{N}$-terminal pseudo signal peptide. J Biol Chem 281: 24910-24921.

176. Huang Y, Wilkinson GF, Willars GB (2010) Role of the signal peptide in the synthesis and processing of the glucagon-like peptide-1 receptor. $\mathrm{Br} J$ Pharmacol 159: 237-251.

177. Bazarsuren A, Grauschopf U, Wozny M, Reusch D, Hoffmann E, et al. (2002) In vitro folding, functional characterization, and disulfide pattern of the extracellular domain of human GLP-1 receptor. Biophys Chem 96: 305-318.

178. Wilmen A, Van Eyll B, Göke B, Göke R (1997) Five out of six tryptophan residues in the N-terminal extracellular domain of the rat GLP-1 receptor are essential for its ability to bind GLP-1. Peptides 18: 301-305.

179.Xiao Q, Jeng W, Wheeler MB (2000) Characterization of glucagon-like peptide-1 receptor-binding determinants. J Mol Endocrinol 25: 321-335.

180. Runge S, Thøgersen H, Madsen K, Lau J, Rudolph R (2008) Crystal structure of the ligand-bound glucagon-like peptide-1 receptor extracellular domain. $J$ Biol Chem 283: 11340-11347.

181. Graziano MP, Hey PJ, Borkowski D, Chicchi GG, Strader CD (1993) Cloning and functional expression of a human glucagon-like peptide-1 receptor. Biochem Biophys Res Commun 196: 141-146.

182. Chen Q, Miller LJ, Dong M (2010) Role of N-linked glycosylation in biosynthesis, trafficking, and function of the human glucagon-like peptide 1 receptor. Am J Physiol Endocrinol Metab 299: E62-68.

183. Whitaker GM, Lynn FC, McIntosh CH, Accili EA (2012) Regulation of GIP and GLP1 receptor cell surface expression by $\mathrm{N}$-glycosylation and receptor heteromerization. PLoS One 7: e32675.

184. Achour L, Labbé-Jullié C, Scott MG, Marullo S (2008) An escort for GPCRs: implications for regulation of receptor density at the cell surface. Trends Pharmacol Sci 29: 528-535.

185. Duvernay MT, Filipeanu CM, Wu G (2005) The regulatory mechanisms of export trafficking of $\mathrm{G}$ protein-coupled receptors. Cell Signal 17: 1457-1465.

186. Marshall RD (1974) The nature and metabolism of the carbohydrate-peptide linkages of glycoproteins. Biochem Soc Symp : 17-26.

187. Elbein AD (1987) Inhibitors of the biosynthesis and processing of $\mathrm{N}$-linked oligosaccharide chains. Annu Rev Biochem 56: 497-534.

188. Balzarini J (2007) Targeting the glycans of glycoproteins: a novel paradigm for antiviral therapy. Nat Rev Microbiol 5: 583-597.

189. Helenius A, Aebi M (2001) Intracellular functions of N-linked glycans. Science 291: 2364-2369.

190. Varki A, Cummings RD, Esko JD, Freeze HH, Stanley P, et al. (2009) Essentials of Glycobiology. 2nd Edition. Cold Spring Harbour Laboratory Press, New York.

191. An HJ, Froehlich JW, Lebrilla CB (2009) Determination of glycosylation sites and site-specific heterogeneity in glycoproteins. Curr Opin Chem Biol 13: 421 426.

192.Brooks SA (2009) Strategies for analysis of the glycosylation of proteins: current status and future perspectives. Mol Biotechnol 43: 76-88.

193. Sadeghi H, Birnbaumer M (1999) O-Glycosylation of the V2 vasopressin receptor. Glycobiology 9: 731-737.

194.Petaja-Repo UE, Hogue M, Laperriere A, Walker P, Bouvier M (2000) Export from the endoplasmic reticulum represents the limiting step in the maturation and cell surface expression of the human delta opioid receptor. J Biol Chem 275: $13727-13736$.

195. Göke R, Just R, Lankat-Buttgereit B, Göke B (1994) Glycosylation of the GLP-
1 receptor is a prerequisite for regular receptor function. Peptides 15: 675-681.

196. Widmann C, Dolci W, Thorens B (1995) Agonist-induced internalization and recycling of the glucagon-like peptide- 1 receptor in transfected fibroblasts and in insulinomas. Biochem J $310: 203-214$.

197. Strader CD, Fong TM, Graziano MP, Tota MR (1995) The family of G-proteincoupled receptors. FASEB J 9: 745-754.

198. Mathi SK, Chan Y, Li X, Wheeler MB (1997) Scanning of the glucagon-like peptide-1 receptor localizes $G$ protein-activating determinants primarily to the $\mathrm{N}$ terminus of the third intracellular loop. Mol Endocrinol 11: 424-432.

199. Takhar S, Gyomorey S, Su RC, Mathi SK, Li X, et al. (1996) The third cytoplasmic domain of the GLP-1[7-36 amide] receptor is required for coupling to the adenylyl cyclase system. Endocrinology 137: 2175-2178.

200. Heller RS, Kieffer TJ, Habener JF (1996) Point mutations in the first and third intracellular loops of the glucagon-like peptide-1 receptor alter intracellular signaling. Biochem Biophys Res Commun 223: 624-632.

201. López de Maturana R, Treece-Birch J, Abidi F, Findlay JB, Donnelly D (2004) Met-204 and Tyr-205 are together important for binding GLP-1 receptor agonists but not their $\mathrm{N}$-terminally truncated analogues. Protein Pept Lett 11 15-22.

202. Koole C, Wootten D, Simms J, Miller LJ, Christopoulos A, et al. (2012) Second extracellular loop of human glucagon-like peptide-1 receptor (GLP-1R) has a critical role in GLP-1 peptide binding and receptor activation. J Biol Chem 287: 3642-3658.

203. Koole C, Wootten D, Simms J, Savage EE, Miller LJ, et al. (2012) Second extracellular loop of human glucagon-like peptide-1 receptor (GLP-1R) differentially regulates orthosteric but not allosteric agonist binding and function. J Biol Chem 287: 3659-3673.

204. Dong M, Lam PC, Pinon DI, Orry A, Sexton PM, et al. (2010) Secretin occupies a single protomer of the homodimeric secretin receptor complex: insights from photoaffinity labeling studies using dual sites of covalent attachment. J Biol Chem 285: 9919-9931.

205.Dong M, Pinon DI, Miller LJ (2012) Site of action of a pentapeptide agonist at the glucagon-like peptide-1 receptor. Insight into a small molecule agonistbinding pocket. Bioorg Med Chem Lett 22: 638-641.

206. Dong MQ, Pinon DI, Cox RF, Miller LJ. (2004) Molecular approximation between a residue in the amino-terminal region of calcitonin and the third extracellular loop of the class B G protein-coupled calcitonin receptor. Journal of Biological Chemistry 279: 31177-31182.

207. Bisello A, Adams AE, Mierke DF, Pellegrini M, Rosenblatt M, et al. (1998) Parathyroid hormone-receptor interactions identified directly by photocrosslinking and molecular modeling studies. J Biol Chem 273: 22498-22505.

208. Dong M, Li Z, Pinon DI, Lybrand TP, Miller LJ (2004) Spatial approximation between the amino terminus of a peptide agonist and the top of the sixth transmembrane segment of the secretin receptor. J Biol Chem 279: 2894 2903.

209. Beinborn M, Worrall Cl, McBride EW, Kopin AS (2005) A human glucagon-like peptide-1 receptor polymorphism results in reduced agonist responsiveness. Regul Pept 130: 1-6.

210. Al-Sabah S, Donnelly D (2003) The positive charge at Lys-288 of the glucagonlike peptide-1 (GLP-1) receptor is important for binding the $\mathrm{N}$-terminus of peptide agonists. FEBS Lett 553: 342-346.

211. Hausdorff WP, Campbell PT, Ostrowski J, Yu SS, Caron MG, et al. (1991) A small region of the beta-adrenergic receptor is selectively involved in its rapid regulation. Proc Natl Acad Sci U S A 88: 2979-2983.

212. Benya RV, Fathi Z, Battey JF, Jensen RT (1993) Serines and threonines in the gastrin-releasing peptide receptor carboxyl terminus mediate internalization. J Biol Chem 268: 20285-20290.

213. Kuramasu A, Sukegawa J, Yanagisawa T, Yanai K (2006) Recent advances in molecular pharmacology of the histamine systems: roles of $\mathrm{C}$-terminal tails of histamine receptors. J Pharmacol Sci 101: 7-11.

214. McArdle CA, Franklin J, Green L, Hislop JN (2002) The gonadotrophinreleasing hormone receptor: signalling, cycling and desensitisation. Arch Physiol Biochem 110: 113-122.

215.Bermak JC, Li M, Bullock C, Zhou QY (2001) Regulation of transport of the 
dopamine D1 receptor by a new membrane-associated ER protein. Nat Cell Biol 3: 492-498.

216. Bockaert J, Marin P, Dumuis A, Fagni L (2003) The 'magic tail' of G proteincoupled receptors: an anchorage for functional protein networks. FEBS Lett 546: 65-72.

217. Harris BZ, Lim WA (2001) Mechanism and role of PDZ domains in signaling complex assembly. J Cell Sci 114: 3219-3231.

218. Hung AY, Sheng M (2002) PDZ domains: structural modules for protein complex assembly. J Biol Chem 277: 5699-5702.

219.Deretic D, Williams AH, Ransom N, Morel V, Hargrave PA, et al. (2005) Rhodopsin $\mathrm{C}$ terminus, the site of mutations causing retinal disease, regulates trafficking by binding to ADP-ribosylation factor 4 (ARF4). Proc Natl Acad Sci U S A 102: 3301-3306.

220. Cao W, Luttrell LM, Medvedev AV, Pierce KL, Daniel KW, et al. (2000) Direct binding of activated $\mathrm{c}-\mathrm{Src}$ to the beta 3-adrenergic receptor is required for MAP kinase activation. J Biol Chem 275: 38131-38134.

221. Robertson DN, Johnson MS, Moggach LO, Holland PJ, Lutz EM, et al. (2003) Selective interaction of ARF1 with the carboxy-terminal tail domain of the 5-HT2A receptor. Mol Pharmacol 64: 1239-1250.

222. Ferguson SS (2001) Evolving concepts in G protein-coupled receptor endocytosis: the role in receptor desensitization and signaling. Pharmacol Rev 53: 1-24.

223.Böhm SK, Grady EF, Bunnett NW (1997) Regulatory mechanisms that modulate signalling by G-protein-coupled receptors. Biochem J $322: 1-18$.

224. Tobin AB (2008) G-protein-coupled receptor phosphorylation: where, when and by whom. Br J Pharmacol 153 Suppl 1: S167-176.

225. Trowbridge IS, Collawn JF, Hopkins CR (1993) Signal-dependent membrane protein trafficking in the endocytic pathway. Annu Rev Cell Biol 9: 129-161.

226. Ohno H, Stewart J, Fournier MC, Bosshart H, Rhee I, et al. (1995) Interaction of tyrosine-based sorting signals with clathrin-associated proteins. Science 269: $1872-1875$

227. Sandoval IV, Bakke O (1994) Targeting of membrane proteins to endosomes and lysosomes. Trends Cell Biol 4: 292-297.

228. Widmann C, Dolci W, Thorens B (1996) Desensitization and phosphorylation of the glucagon-like peptide-1 (GLP-1) receptor by GLP-1 and 4-phorbol 12-myristate 13-acetate. Mol Endocrinol 10: 62-75.

229. Vazquez P, Roncero I, Blazquez E, Alvarez E. (2005) The cytoplasmic domain close to the transmembrane region of the glucagon-like peptide-1 receptor contains sequence elements that regulate agonist-dependent internalisation. J Endocrinol 186: 221-231.

230. Thorens B (1992) Expression cloning of the pancreatic beta cell receptor for the gluco-incretin hormone glucagon-like peptide 1. Proc Natl Acad Sci U S A 89: 8641-8645.

231.De Vos A, Heimberg H, Quartier E, Huypens $P$, Bouwens L, et al. (1995) Human and rat beta cells differ in glucose transporter but not in glucokinase gene expression. J Clin Invest 96: 2489-2495.

232. Holz GG (2004) Epac: A new cAMP-binding protein in support of glucagon-like peptide-1 receptor-mediated signal transduction in the pancreatic beta-cell. Diabetes 53: 5-13
233. Matschinsky FM (2002) Regulation of pancreatic beta-cell glucokinase: from basics to therapeutics. Diabetes 51 Suppl 3: S394-404.

234. Holz GG 4th, Kühtreiber WM, Habener JF (1993) Pancreatic beta-cells are rendered glucose-competent by the insulinotropic hormone glucagon-like peptide-1(7-37). Nature 361: 362-365.

235. Montrose-Rafizadeh C, Egan JM, Roth J (1994) Incretin hormones regulate glucose-dependent insulin secretion in RIN 1046-38 cells: mechanisms of action. Endocrinology 135: 589-594.

236. Kashima Y, Miki T, Shibasaki T, Ozaki N, Miyazaki M, et al. (2001) Critical role of cAMP-GEFII--Rim2 complex in incretin-potentiated insulin secretion. J Biol Chem 276: 46046-46053.

237. Ozaki N, Shibasaki T, Kashima Y, Miki T, Takahashi K, et al. (2000) cAMP GEFII is a direct target of CAMP in regulated exocytosis. Nat Cell Biol 2: 805811.

238. Kang G, Joseph JW, Chepurny OG, Monaco M, Wheeler MB, et al. (2003) Epac-selective cAMP analog 8-pCPT-2'-O-Me-cAMP as a stimulus for $\mathrm{Ca2+-}$ induced $\mathrm{Ca} 2+$ release and exocytosis in pancreatic beta-cells. J Biol Chem 278: 8279-8285

239. Tsuboi T, da Silva Xavier G, Holz GG, Jouaville LS, Thomas AP et al. (2003) Glucagon-like peptide-1 mobilizes intracellular $\mathrm{Ca} 2+$ and stimulates mitochondrial ATP synthesis in pancreatic MIN6 beta-cells. Biochem J 369: 287-299

240. Kasai K, Ohara-Imaizumi M, Takahashi N, Mizutani S, Zhao S, et al. (2005) Rab27a mediates the tight docking of insulin granules onto the plasma membrane during glucose stimulation. J Clin Invest 115: 388-396.

241. Jhala US, Canettieri G, Screaton RA, Kulkarni RN, Krajewski S, et al. (2003) cAMP promotes pancreatic beta-cell survival via CREB-mediated induction of IRS2. Genes Dev 17: 1575-1580.

242. Wang Q, Li L, Xu E, Wong V, Rhodes C, et al. (2004) Glucagon-like peptide-1 regulates proliferation and apoptosis via activation of protein kinase $B$ in pancreatic INS-1 beta cells. Diabetologia 47: 478-487.

243. Ruvinsky I, Sharon N, Lerer T, Cohen H, Stolovich-Rain M, et al. (2005) Ribosomal protein S6 phosphorylation is a determinant of cell size and glucose homeostasis. Genes Dev 19: 2199-2211.

244. Tokuyama Y, Matsui K, Egashira T, Nozaki O, Ishizuka T, et al. (2004) Five missense mutations in glucagon-like peptide 1 receptor gene in Japanese population. Diabetes Res Clin Pract 66: 63-69.

245. Salapatek AM, MacDonald PE, Gaisano HY, Wheeler MB (1999) Mutations to the third cytoplasmic domain of the glucagon-like peptide 1 (GLP-1) receptor can functionally uncouple GLP-1-stimulated insulin secretion in HIT-T15 cells. Mol Endocrinol 13: 1305-1317.

246. George SR, O'Dowd BF, Lee SR (2002) G-protein-coupled receptor oligomerization and its potential for drug discovery. Nature Reviews Drug Discovery 1: 808-820.
This article was originally published in a special issue, GPCR Signalling \& Diabetic Complications handled by Editor(s). Dr. Wenbo Zhang, The University of Texas Medical Branch, USA 